\title{
Politiser le désarroi militant
}

Histoire sociale de la « végéphobie » dans le mouvement animaliste français

Politicizing Activist Discontent. A Social History of "Vegephobia" in the French Animal Rights Movement

Politizar la decepción militante. Historia social de la « fobia vegana » en el movimiento animalista francés

\section{Fabien Carrié}

\section{(2) OpenEdition}

Journals

Édition électronique

URL : http://journals.openedition.org/bssg/246

DOI : $10.4000 /$ bssg.246

ISSN : 2490-9424

Éditeur

Presses universitaires de Vincennes

Référence électronique

Fabien Carrié, « Politiser le désarroi militant », Biens Symboliques / Symbolic Goods [En ligne], 2 | 2018, mis en ligne le 12 avril 2018, consulté le 04 mars 2021. URL : http://journals.openedition.org/bssg/246 ; DOI : https://doi.org/10.4000/bssg.246 


\section{Politiser le désarroi militant}

\author{
Histoire sociale de la « végéphobie » dans \\ le mouvement animaliste français
}

\section{Politicizing Activist Discontent}

\author{
A Social History of "Vegephobia" \\ in the French Animal Rights Movement
}

Fabien Carrié

traduction | translation

Michelle Arriss | Delaina Haslam | Séverine Sofio

Contrairement à leurs équivalents britanniques ou nord-américains, les groupes français se revendiquant de la cause animale ${ }^{1}-$ et, plus particulièrement, de ses déclinaisons contemporaines comme l'antispécisme ${ }^{2}$ - ont rencontré jusque-là d'importantes difficultés à légitimer leurs prétentions à la prise de parole au nom des "bêtes ". Si depuis peu les lignes bougent, militer en France pour l'animal demeure une activité difficile : à l'incompréhension que suscite, chez les proches des militant $\cdot e \cdot s$, l'adoption de modes de

1 Le présent article a bénéficié de la relecture aussi attentive que constructive des évaluateurs et évaluatrices de la revue, qu'ils et elles en soient chaleureusement remerciée.e.s.

2 Mouvement social contemporain dont les tenants revendiquent l'abolition de toute discrimination en fonction de l'espèce d'appartenance, l'exploitation des animaux par l'humain, de quelque manière que ce soit, étant dès lors assimilée au racisme et au sexisme.
Unlike their British and North American equivalents, French groups supporting animal rights $^{1}$ - especially contemporary forms such as anti-speciesism ${ }^{2}$ - have always come up against significant challenges in gathering support for their claims when speaking out in the name of the cause. Although the lines have been shifting recently, campaigning for animals in France remains a difficult task involving a lack of understanding on the part of those close to activists who take on alternative consumption choices, such as veganism ${ }^{3}$ and the incredulity of a public which knows

1 This article has benefited from close and constructive feedback from the reviewers and editors of the journal, for which I am truly grateful.

2 Contemporary movement in support of ending all discrimination based on species membership, meaning any means of exploitation of animals by humans is thereby equated with racism or sexism.

3 The term "veganism," a contraction of "vegetarianism," refers to a specific way of life that excludes any product (food, clothes, etc.) or any activity 
consommation alternatifs comme le véganisme ${ }^{3}$ s'ajoute en effet l'incrédulité d'un public peu au fait de cette cause. De cela découlent un important turn over, un renouvellement rapide des effectifs au sein des organisations, ainsi qu'une tendance à la réflexivité sur les pratiques militantes - tendance qui se traduit par la tenue annuelle des Estivales de la question animale, où convergent militant.e.s et intellectuel-le·s afin d'évoquer le devenir du mouvement (Traïni 2010, 2012). Surtout, l'espace du militantisme animaliste français est le théâtre depuis une dizaine d'années de l'émergence ponctuelle de labels et de mots d'ordre controversés, forgés dans l'optique de politiser la cause, et pour partie constitués en référence aux expériences malheureuses des porte-paroles revendiqués des bêtes. C'est le cas de la notion de "végéphobie ", néologisme forgé par analogie avec le terme d'homophobie et désignant l'ensemble des vexations subies par les végétarien·ne·s, végétalien·ne·s et vegans - autant de discriminations qui seraient l'expression de l'ordre spéciste de la société, d'un mode de domination multiforme dont les premières victimes seraient les animaux exploités pour leur chair, leur peau ou leurs aptitudes physiques. On se propose ici de réfléchir au processus d'élaboration de cette notion de végéphobie, aux conditions de possibilité de sa structuration et aux difficultés actuelles pour la légitimer au sein du mouvement animaliste (Ebel \& Fiala 1983 ; Krieg-Planque 2009). La perspective adoptée ici est au croisement de l'histoire sociale des idées politiques et des courants d'analyse des mouvements sociaux et des partis politiques comme entreprises culturelles (Gusfield 1994 ; Sawicki 2001 ; Skornicki \&

3 Le terme de véganisme, ou veganism, contraction de vegetarianism, désigne un mode de vie excluant tout produit (alimentaire, vestimentaire, etc.) ou toute activité (loisirs, transport, etc.) impliquant l'exploitation d'animaux, contrairement aux végétariens et aux végétaliens qui se définissent essentiellement par rapport à la question de l'alimentation, à travers leur refus de consommer des animaux (végétariens) et tout produit issu des animaux (végétaliens) little about the cause. This leads to a high turnover of members within organizations, as well as a tendency towards reflexivity on activist practices - a tendency reflected in the annual Estivales de la question animale, an animal rights forum held for ten days each summer where activists and thinkers converge to discuss the state of the movement (Traïni 2010, 2012). In the past ten years or so, the French animal rights activism space has been the main forum for the sporadic emergence of controversial labels and slogans resulting from a desire to politicize the cause, and created in part with reference to the negative experiences of those who claim to speak on behalf of animals. This is the case for the term "vegephobia," a neologism created out of analogy with the term "homophobia," and which refers to all offences committed against vegetarians and vegans. It also denotes any discrimination that is the expression of society's speciesist position - of a multidimensional domination of which the first victims are animals exploited for their flesh, skins, or physical attributes. This article proposes to reflect on the development of the notion of vegephobia, the conditions enabling its structuring, and the current difficulties for its legitimization within the animal rights movement (Ebel \& Fiala 1983; Krieg-Planque 2009). The perspective adopted here is at the interface between the social history of political ideas and trends of analysis of social movements and political parties as cultural enterprises (Gusfield 1994; Sawicki 2001; Skornicki \& Tournadre 2015). By following the trajectory of this symbolic innovation, from its production to its reception by activists, the aim is to expose the mechanisms used by minority activist groups who attempt to reverse the stigma, politicizing the difficulties they face,

(transportation, leisure activities, etc.) derived from the exploitation of animals, whereas vegetarianism mainly concerns food consumption (abstaining from eating animals and sometimes also anything produced by animals) 
Tournadre 2015). En suivant la «trajectoire » de cette novation symbolique, depuis sa production jusqu'à sa réception par les militant·e.s, on entend mettre au jour les mécanismes par le biais desquels des collectifs militants minoritaires s'essaient à retourner leur stigmate, à politiser les difficultés qu'ils rencontrent et à légitimer leurs prétentions à la prise de parole dans l'espace public (Cherry 2010 ; Belorgey, Chateigner, Hauchecorne, Pénissat 2011)

Pour ce faire, l'approche ethnographique a été privilégiée. Le dépouillement et l'étude des ouvrages, articles de revue et tracts produits par les antispécistes s'articulent à la conduite d'entretiens et à l'observation des événements et des milieux au sein desquels ils s'efforcent de diffuser leurs concepts (Hauchecorne 2012). De 2007 à 2012 dans le cadre d'un mémoire de master puis d'une thèse, ont été réalisés plus de 70 entretiens semi-directifs avec des agent.e.s investi.e.s au sein de cette cause. II s'agissait d'intellectuel.le's et d'animateur.rice's du mouvement comme de « simples " militant.e.s aux investissements multiformes habitué $\cdot$ - $s$ des stands d'information et des manifestations de rue en faveur du véganisme ou pour l'abolition de l'expérimentation animale, bénévoles des refuges d'animaux ou participant.e.s ponctuel.le.s à des sabotages de chasse. Les observations ethnographiques relèvent également de situations variées : veggie pride $^{4}$, manifestation non autorisée devant le Salon de l'agriculture pour l'abolition de la viande, happenings et protestations devant des locaux de compagnies aériennes ou de laboratoires pharmaceutiques, Estivales de la question animale, réunions plus informelles d'associations locales ou de rassemblements nationaux, conférences et projections organisées par des groupes militants. Cette enquête de terrain, facilitée par une conversion au

4 La veggie pride est la manifestation annuelle de la fierté d'être végétarien pour les droits des animaux. and legitimizing their attempts to speak out in the public space (Cherry 2010; Belorgey, Chateigner, Hauchecorne, Pénissat 2011).

An ethnographic approach was chosen in order to do this. An effort to survey and study books, journal articles, and leaflets produced by anti-speciesists was combined with interviews and the observation of events and of the communities in which the movement strives to disseminate its concepts (Hauchecorne 2012). From 2007 to 2012, within the framework of a master's dissertation and then a thesis, more than seventy semi-structured interviews were conducted with agents involved with this cause. The interviewees were intellectuals and leaders of the movement from "simple" activists to those involved on several levels - regular attendants at information stalls and street demonstrations in support of veganism or banning experiments on animals, volunteers at animal shelters, or those who sometimes take part in hunt sabotages. The ethnographic observations also took place in varied situations: at Veggie Pride ${ }^{4}$ at an illegal demonstration outside the Paris International Agricultural Show calling for the abolition of meat; happenings and protests in front of airline companies or pharmaceutical laboratories; at the Estivales de la question animale; at informal meetings of local associations; and at national meetings, conferences, and screenings organized by activist groups. This field study, facilitated by a conversion to vegetarianism at the start of the research, allowed the researcher

4 "Veggie Pride" is the annual demonstration of the pride of being vegetarian in support of animals. 
végétarisme au début de la recherche, a permis d'observer en acte les tentatives de déploiement de cette notion de végéphobie au sein du mouvement animaliste français.

On commencera par envisager la genèse en Grande-Bretagne et aux États-Unis du mouvement contemporain de la libération animale. II s'agira à partir de là de s'intéresser aux difficultés rencontrées par les passeur.se.s français.es pour implanter ce mouvement social. Le désarroi de ces importateur.rice.s et les échecs successifs de la mise en circulation de ces schèmes dans différents espaces sociaux déterminent pour partie l'élaboration d'une catégorie comme celle de la végéphobie et, plus largement, les ajustements qu'ils et elles opèrent à la croisée des années 1990

et 2000 .

\section{Antispécisme et libération animale : la genèse anglo-américaine d'une entreprise radicale de représentation politique des bêtes}

II faut en préalable revenir au moment d'émergence, dans les années 1970 en Grande-Bretagne et aux États-Unis, du mouvement social de « libération animale ». Deux raisons justifient ce détour. La première résulte du fait que le « malheur » du militantisme animaliste français contemporain se mesure à l'aune du succès de son pendant anglo-américaine, en ce qu'il est une importation contrariée de ses schèmes, mots d'ordre et modes d'action. C'est de ce décalage que procède pour partie le désarroi persistant des porte-paroles des bêtes en France. Il est au principe d'expériences et d'impressions qui vont nourrir la formalisation de la végéphobie. La seconde tient à ce que l'affirmation du mouvement de libération animale en Grande-Bretagne et aux États-Unis et le développement d'une notion comme le spécisme relèvent également d'une forme de politisation du malheur militant de l'époque. Ceci n'a pas manqué de peser dans les tentatives récentes des antispécistes en France to observe active attempts at spreading the notion of vegephobia within the French animal rights movement.

We will begin by considering the origins of the contemporary animal liberation movement in Great Britain and the United States. Next we will consider the difficulties encountered by these groups' French importers in establishing this social movement. The dissatisfaction felt by these importers and the successive failures to circulate their framework within various social spaces partly determined the development of a label such as vegephobia and, more generally, the adjustments they made during the 1990s and 2000s.

\section{Anti-speciesism and Animal Liberation: The Beginnings of a Radical Movement for Animals' Political Representation in the UK and the US}

We must first go back to the emergence in the 1970s in Great Britain and the United States of the "animal liberation" social movement. There are two reasons for making this detour. The first stems from the fact that the problems facing contemporary French animal rights activism can be measured against the success of its British and American counterparts: it is an importation thwarted in its ideas, slogans, and strategies. This divergence is partly behind the persistent discontent of animal rights advocates in France. It is experiences and impressions that fuel the formalization of vegephobia. The second reason lies in what the affirmation of the animal liberation movement in the UK and the US and the development of a concept such as speciesism also indicate about a form of politicization of current activist discontent. This has certainly weighed on recent anti-speciesist activity in France to mobilize vegetarians against the discrimination they arguably suffer on a daily basis. 
pour mobiliser les végétarien·ne·s contre les discriminations qu'ils et elles subiraient quotidiennement.

\section{La légitimation de l'antispécisme dans le champ intellectuel..}

Durant les années 1960 et 1970, les organisations britanniques de défense des animaux voient affluer des militant·e.s souvent jeunes, d'origine urbaine, issus des classes populaires et d'une petite classe moyenne. Ce recrutement massif a contribué à l'intensification des tensions entre une base militante renouvelée - volontiers favorable à l'action directe - et les états-majors de ces organisations, plus modérés. Prédominent alors des groupes qui revendiquent une critique sectorielle de l'exploitation des bêtes, en se focalisant sur des catégories spécifiques d'animaux ou sur telle ou telle pratique jugée inacceptable du fait de sa cruauté ou des souffrances qu'elle suscite (expérimentation animale, chasse, combats de chiens, maltraitance des animaux dans les fermes industrielles). La configuration des porte-paroles des bêtes est par ailleurs affectée par une dynamique de " scientifisation " (Fabiani 1985 ; Habermas 1990). Expert.e.s du bien-être animal et chercheur.e.s issu·e.s d'une discipline commel'éthologie qui connaît un fort développement en Grande-Bretagne (Burkhardt 2005 ; Chavot 1994) diffusent et imposent des normes techniques pour la gestion de la souffrance des bêtes dans les dispositifs d'exploitation (Wilson 2002 ; Woods 2012). Ces évolutions entraînent un accroissement des coûts de la prise de parole au nom des animaux et une relégation des militant·e.s les moins doté.e.s et des nouveaux entrants aux marges de la configuration. Des scissions s'ensuivent et des collectifs se créent, développant des méthodes d'action novatrices comme le sabotage de chasse ou la destruction de dispositifs d'exploitation. Des consensus s'instaurent au sein de ces groupements pour l'adoption du régime végétarien, et des liens se constituent avec les organisations de réforme alimentaire. Ils sont le signe d'un redéploiement et de nouvelles lignes de force

\section{The Legitimization of Anti-speciesism in the Intellectual Field}

In the 1960s and 1970s, British animal rights organizations saw a sharp increase in the number of activists; they were often young, from urban working- and lower-middle-class backgrounds. This large-scale influx contributed to an increase in tension between a renewed activist base - which willingly supported direct action and the more moderate leaders of these organizations. At that time, there was a predominance of groups who voiced sectoral criticism of animal exploitation, focusing on specific categories of animal or on practices deemed unacceptable because of their cruelty or suffering caused (animal experiments, hunting, dog fighting, and abuse of animals in factory farms, for instance). The formation and set-up of the proponent for animal rights was also affected by a certain "scientification" dynamic (Fabiani 1985; Habermas 1990). Animal welfare experts and researchers from disciplines such as ethology which experienced rapid growth in the UK (Burkhardt 2005; Chavot 1994) circulated and enforced technical standards for the management of animal suffering in exploitation (Wilson 2012; Woods 2002). These developments led to an increase in the cost of speaking out for animals and a relegation of the least-endowed activists and the newest entrants at the sidelines of the movement. Splits ensued, and groups formed that developed innovative methods of action such as hunt sabotage and the destruction of exploitation equipment. Consensus was established within these groupings to adopt a vegetarian diet, and links to organizations for food reform were built. These were signs of a shift in the tenets of the British animal rights movement (Carrié 2017). It was in this context, within the student population and the militant vegetarian groups of Oxford that the concept of speciesism emerged, as a 
au sein du mouvement animaliste britannique (Carrié 2017). C'est dans ce contexte, au sein des milieux étudiants et des groupements militants végétariens d'Oxford, qu'est forgée la notion de spécisme, conçue comme une critique systémique de l'ensemble des formes d'exploitation des animaux, au fondement du mouvement de

libération animale.

On ne peut toutefois comprendre le succès de mouvements comme l'antispécisme, sans tenir compte de la diffusion de ces idées vers les États-Unis. C'est par le travail d'un « passeur de sens » comme Peter Singer que ces biens symboliques vont circuler au-delà des limites du microcosme oxfordien. L'intellectuel australien s'installe à Oxford avec sa femme en 1969 afin d'obtenir son doctorat en philosophie (Singer 1975). C'est au hasard d'une conversation avec des activistes végétariens que les époux, militants pacifistes mobilisés contre la guerre du Vietnam, découvrent la « question animale ", décidant dans la foulée d'adopter un régime végétarien et de s'engager pour cette cause. II faut cependant attendre 1973 pour que l'intérêt de Singer pour ces thématiques se traduisent en un projet intellectuel. Alors lecturer à l'Université de New York, il publie dans la revue New York Review of Books une note critique, intitulée «Animal Liberation » (Singer 1973). Le retentissement important dans les sphères intellectuelles et médiatiques newyorkaises du texte présenté comme manifeste d'un nouveau mouvement égalitaire (Singer 1998) incite son auteur à faire paraître deux ans plus tard un ouvrage éponyme, synthèse des travaux qu'il a entamés sur la question depuis son séjour à Oxford. Écrit d'abord à destination des « profanes » et des militant.e.s, le succès de Animal Liberation, sa large diffusion des deux côtés de l'Atlantique, consacrent Peter Singer comme figure intellectuelle majeure de la cause, voire comme père fondateur d'un mouvement social inédit, le mouvement de libération animale. systemic criticism of all forms of animal exploitation, which formed the basis of the animal liberation movement.

We cannot, however, understand the success of slogans such as anti-speciesism without considering the spread of these ideas to the US. It through the work of people such as Peter Singer, who facilitated the exchange of ideas, that these symbolic goods were transmitted beyond the limits of the Oxford microcosm. The Australian intellectual moved to Oxford with his wife in 1969 to study for his doctorate in philosophy (Singer 1975). It was through a conversation with vegetarian activists that the couple, who were pacifists opposed to the Vietnam War, discovered animal issues, deciding there and then to adopt a vegetarian diet and commit to this cause. However, it was not until 1973 that Singer would translate his interest in these themes into an academic project. When working as a New York University lecturer, he published a critical article in the New York Review of Books entitled "Animal Liberation" (Singer 1973). The significant impact in the New York intellectual and press spheres of this text which was presented as the manifesto of a new egalitarian movement (Singer 1998) encouraged Singer to publish an eponymous book two years later, which was a synthesis of the work he had begun on the issue since his time at Oxford. Animal Liberation was first written with a "lay" readership and activists in mind, and its success - a wide distribution on both sides of the Atlantic - enshrined Peter Singer as the major intellectual figure of the cause, or even the founding father of a new social movement, animal liberation. 
Le succès social des productions de Peter Singer tient en partie aux qualités formelles du travail de synthèse qu'il propose, qui renvoie aux spécificités de son propre habitus, clivé entre son éthos militant et ses engagements dans le champ intellectuel. Se revendiquant de l'utilitarisme des préférences et d'une figure comme Jeremy Bentham, Singer s'inscrit dans le sillage de jeunes docteur.e.s en philosophie qui, à l'encontre du courant analytique devenu dominant dans le champ philosophique états-unien depuis la fin de la guerre (Hauchecorne \& Pudal 2016), entendent réhabiliter les tendances prescriptives et normatives de la philosophie angloaméricaine. Marqués par les mouvements sociaux de l'époque, ils et elles se focalisent sur des problématiques jusque-là non abordées par la philosophie morale. Les revendications portées par les mouvements féministes, pacifistes ou écologistes, sont, pour eux, autant de points d'entrée pour réhabiliter une pratique philosophique focalisée sur l'aspect concret des questionnements éthiques. Cette nouvelle génération va « mettre à jour » la tradition prescriptive de la philosophie morale anglophone, formulant les préceptes d'une éthique appliquée (Singer 2006). En prenant notamment appui sur les développements des sciences, il s'agit de justifier d'une philosophie ancrée dans le réel, qui puisse aider les gens à faire de bons choix moraux, dans une société considérée comme de plus en plus complexe (Rorty 2008). Les prises de position de Singer sur la « question animale » sont dans la droite ligne des productions de ces auteurs (Singer 1986). La dénonciation du traitement réservé aux animaux domestiques dans les sociétés contemporaines lui permet d'affirmer une position de prescripteur moral, apte à révéler les injustices et à définir les attitudes légitimes à adopter dans nos rapports avec les bêtes. Argumentant à partir des découvertes récentes en primatologie et en éthologie sur les comportements des animaux et l'expression de leurs émotions, et des travaux réalisés en neurologie sur les mécanismes de la douleur, l'auteur défend l'idée d'une expérience
The social success of Singer's productions can partly be explained by the formal qualities of the synthesis he proposed, which referred to the distinctions of his own habitus, cleaved between his activist ethos and his involvement in the intellectual field. Claiming a position of preference utilitarianism and proximity to figures such as Jeremy Bentham, Singer followed in the wake of young doctors of philosophy who, when faced with the analytical trend that had become dominant in the American philosophical field since the end of the war (Hauchecorne \& Pudal 2016), strived to rehabilitate the prescriptive and normative trends of British and American philosophy. Influenced by social movements of the time, they focused on issues not previously addressed by moral philosophy. The claims made by the feminist, pacifist, and environmentalist movements were, for them, entry points for the rehabilitation of a philosophical practice focused on the concrete aspect of ethical questions. This new generation was to bring the prescriptive tradition of moral philosophy of the English-speaking world "up to date," formulating the precepts of applied ethics (Singer 2006). Building on, in particular, developments in science, the aim was to justify a philosophy that was rooted in reality, which could help people make good moral choices in a society viewed as increasingly complex (Rorty 2008). Singer's stances on animal issues were in line with these authors' works (Singer 1986). The denunciation of the treatment of domestic animals in contemporary societies affirmed his position as a moral prescriber, able to reveal injustices and define legitimate attitudes to adopt in our relationships with animals. Arguing from the basis of recent discoveries in primatology and ethology on the behaviour of animals and their expression of emotions, and on work carried out in neurology on mechanisms of pain, the author defends the idea of a sentient experience common to humans and animals. It is in terms of this shared sensitivity that the morality of exploitation methods must be considered. Here Singer adapted the theoretical model of Richard Mervyn Hare, 
sensible commune aux humains et aux bêtes. C'est à l'aune de cette sensibilité partagée que doivent s'apprécier la moralité des dispositifs d'exploitation. Singer adapte ici le modèle théorique de Richard Mervyn Hare, qui postule que la moralité d'un énoncé se juge à son universalité, au fait que chaque individu puisse se reconnaître comme sujet de celui-ci (Hare 1962 ; Singer 2002). Les premiers chapitres de Animal Liberation, qui dépeignent les formes contemporaines d'élevage intensif et d'expérimentation animale, et les souffrances qu'elles suscitent, sont ainsi autant d'invitations faites au lecteur.rice à se projeter dans l'expérience sensibles des bêtes. De cette manière, l'intellectuel entend démontrer l'impossible universalisation des traitements qu'elles subissent et, par là, leur immoralité. En mobilisant à son profit la légitimité des connaissances scientifiques produites sur les animaux et leurs comportements, il parvient à affirmer un magistère moral sur la « question animale ». Ce magistère remet en cause le monopole des scientifiques du vivant et des experts de la science du bien-être animal en matière de parole légitime sur les bêtes. À la tendance dominante d'une gestion de plus en plus distanciée des animaux domestiques, il oppose le principe d'une critique politique systémique engagée, dérivée pour partie des mouvements protestataires de l'époque.

\section{... et dans l'espace militant}

Singer va tirer parti de ses échanges avec les militants britanniques, systématisant à partir de notions comme « libération animale » ou « spécisme » la représentation d'une mobilisation pour l'animal dans la continuité des mouvements progressistes de la période. Dans un contexte perçu comme marquant un essoufflement général des luttes (Granjon 1985), ses comparaisons et les appels du pied qu'il adresse aux militant·e.s engagé $\cdot e \cdot s$ comme lui dans les mouvements pacifistes et minoritaires ne peuvent se comprendre exclusivement à l'aune de leur efficacité rhétorique supposée et de which postulates that the morality of a statement is judged by its universality, in such a way that every individual can recognize themselves as subject to this (Hare 1962; Singer 2002). The first chapters of Animal Liberation, which depict forms of contemporary intensive farming and animal experimentation and the suffering they cause, are thereby invitations to the reader to project him or herself into the sentient experience of animals. In this way, Singer wishes to demonstrate the impossible universalization of the treatment they suffer and therefore its immorality. By using the legitimacy of scientific knowledge produced about animals and their behaviours to his advantage, he was able to claim moral leadership on animal issues. This leadership questioned the monopoly of life scientists and experts in the science of animal well-being on legitimately speaking about animals. He contrasted the dominant trend of an increasingly distanced management of domestic animals with the principle of a committed, systemic political criticism partly derived from the protest movements of the time.

\section{The Legitimization of Anti-Speciesism in the Activist Field}

Singer took advantage of his exchanges with British activists to systematize the representation of the animal rights movement using concepts such as "animal liberation" and "speciesism" as part of a continuation of progressive movements of the period. In a context perceived as characterized by widespread loss of impetus in social struggles (Granjon 1985), his comparisons and appeals to fellow committed activists of pacifist and minority movements cannot only be understood in terms of their supposed rhetorical effectiveness and tactics against the competing current intellectual trends. The 
leurs effets tactiques contre des courants intellectuels concurrents. Le leitmotiv récurrent dans ses écrits d'un déclin des luttes montre à quel point sa formalisation de l'idéologie " animaliste ", au-delà des seuls enjeux des conflits du champ intellectuel, se trouve conditionnée par des préoccupations renvoyant à sa propre trajectoire militante. Pour Singer, tout se passe comme si son engagement au nom des bêtes était pensé comme une façon de concilier dispositions militantes et activité universitaire.

S'il convient de ne pas surdéterminer l'influence de ses écrits sur l'évolution du mouvement états-unien, il ne faut pas non plus dénier à l'intellectuel toute dimension performative. Les incitations récurrentes aux acteur-rice-s mobilisé $\cdot e \cdot s$ dans le mouvement contre-culturel ont pu favoriser une forme de réinvestissement de l'éthos militant au sein de la cause animale, et plus particulièrement dans les collectifs locaux de militant.e.s et d'activistes, au moment où le mouvement contestataire reflue, donnant le jour à une multiplicité de groupes à assise régionale. II est difficile cependant d'estimer l'ampleur des reconversions que la réception des écrits de Singer a pu susciter. Sans doute fut-elle modeste, au regard d'abord du nombre d'agent.e.s véritablement engagé.e.s dans le mouvement de contestation, du fait également de la multiplicité des luttes dans lesquels les militant.e.s vont par la suite s'investir (MacAdam 1989). Pour autant, les quelques cas connus de reconversion - et plus particulièrement celui de Henry Spira, ancien militant trotskyste, mobilisé dans la lutte pour les droits civiques dans les années 1960 et en voie de désengagement dans les années 1970, qui trouve dans le mouvement de libération animale une nouvelle cause à investir (Munro 2002) - ne sont pas sans effet sur les groupes animalistes. Ces acteur.rice.s importent avec eux des savoir-faire acquis dans les mobilisations contestataires, qui contribuent à diversifier le répertoire tactique des collectifs les plus radicaux, renforçant les spécificités de ces groupements vis-à-vis des organisations plus traditionnellement vouées à la prévention de recurrent leitmotiv in his writing of a decline of struggles shows the extent to which his formalization of the "animalist" ideology - beyond only the issues of the conflicts of the intellectual field was conditioned by concerns linked to his own activist trajectory. For Singer, it was as though his involvement with the animal cause was considered a way of reconciling militant dispositions and academic activity.

While we should not over-emphasize the influence of his writings on the evolution of the movement in the US, nor should we deny him a performative role as an intellectual. The continual inducements to actors involved in the counter-culture movement helped promote a form of reinvestment of the militant ethos into the animal rights cause, and more specifically into local activist and militant groups at a time when the protest movement was receding, giving rise to a multiplicity of regionally based groups. However, it is difficult to estimate the number of the reconversions that the reception of Singer's writings generated. It was undoubtedly modest, first of all in light of the number of agents genuinely committed to the protest movement, and also as a result of the multiplicity of struggles with which activists would go on to engage (MacAdam 1989). Nevertheless, the few known cases of conversion - for example that of Henry Spira, a former Trotskyist activist involved in the civil rights movement of the 1960s and on track for disengagement in the 1970s, who found in the animal liberation movement a new cause to invest in (Munro 2002) - certainly had an effect on animal rights groups. These actors brought with them knowledge acquired from protests, which helped to diversify the tactical repertoire of the most radical groups, strengthening the distinctions of these groups vis-à-vis organizations more traditionally devoted to preventing violence against animals. The echo of these developments and the success of the campaigns carried out in the US encouraged the 
la violence à l'encontre des bêtes. L'écho de ces développements et le succès des campagnes menées aux États-Unis favorisent le retour au Royaume-Uni du discours antispéciste et des mots d'ordre de la libération animale, et bientôt leur généralisation dans

le monde anglophone.

Le coup double réussi de Singer renvoie très largement aux spécificités du champ académique états-unien et à ses rapports d'imbrication avec l'espace militant. Se donne alors à voir une dynamique d'autorenforcement caractéristique des coups doubles : la reconnaissance dans le champ intellectuel des productions de Singer, et à sa suite, des penseurs de l'éthique animale, favorise l'appropriation des labels de libération animale et d'antispécisme par les militant·e.s, ce qui en retour conforte dans l'espace public l'importance de cette question. En définitive, c'est un véritable retournement dans les configurations anglo-saxonnes des groupes de porte-paroles des animaux qu'initie Singer au mitan des années 1970. Les critiques systémiques de l'exploitation des bêtes, jusque-là minoritaires, s'imposent progressivement au détriment des critiques sectorielles auparavant dominantes, opérant ainsi un basculement des valeurs au sein de ces espaces de lutte (Bourdieu 2013).

Le succès du projet de Singer, de même que la reconversion de militant $\cdot$ e.s comme Spira dans ce mouvement naissant, s'expliquent aussi pour partie par la naturalisation précoce, en GrandeBretagne et dans les pays anglophones, de l'idée de représentation politique des bêtes. Les dynamiques successives depuis la fin du $\mathrm{XVIII}^{\mathrm{e}}$ siècle de production, de diffusion et d'institutionnalisation de formes variées de porte-parolats des animaux (protection animale, antivivisectionnisme, humanitarianisme) ont contribué à y légitimer le principe d'une délégation politique des intérêts de ces sans-voix, et à y imposer durablement l'idée d'une représentation return in the UK of anti-speciesist discourse and animal liberation slogans, and then their dissemination throughout the Englishspeaking world.

The "double hit" achieved by Singer refers in broad terms to the specific nature of the US academic field and to its interlinking relations with the activist space. This reveals a dynamic of self-reinforcement characteristic of such a "double hit": the recognition for Singer's work in the academic field, followed by the recognition for thinkers in the sphere of animal ethics, favoured the appropriation of animal liberation and anti-speciesist labels by activists, who in return helped raise the issue's importance in the public arena. Ultimately, Singer initiated a genuine turnaround in the configurations of animal advocacy groups in the US and the UK in the mid-1970s. Systemic criticism of the exploitation of animals, which had until then been marginal, was increasingly enforced over the previously dominant sectoral criticism, thus causing a shift in values within these battlegrounds (Bourdieu 2013).

The success of Singer's project as well as the conversion of activists such as Spira in this nascent movement can also partly be explained by the early adoption in Great Britain and English-speaking countries of the idea of the political representation of animals. The successive dynamics since the end of the eighteenth century of production, diffusion, and institutionalization of various forms of animal advocacy (animal protection, anti-vivisectionism, humanitarianism, and so on) helped to legitimize the principle of a political delegation for the interests of these voiceless creatures, and to impose for the long term the idea of a "lay" and alternative animal representation 
des animaux « profane » et alternative face au monopole de la parole légitime détenue par les scientifiques du vivant, sur tout ce qui relève de la nature (Carrié 2015a). Ceci a facilité l'entreprise des tenants de l'éthique animale, qui ont eu beau jeu à partir de là d'exhumer dans les écrits de militant·e.s animalistes du XIX et du début $d u x^{e}$ siècle les prémices de leur critique systémique de l'exploitation animale. Les ressources conséquentes que font valoir ces agent·e.s, ainsi que les spécificités des configurations nationales dans lesquelles ils s'inscrivent, sont autant de conditions du succès social des notions qu'ils produisent et de la mobilisation collective antispéciste qui se développe fortement à partir de là aux États-Unis et en Grande-Bretagne. II en sera tout autrement dans le cas de l'importation française.

\section{Aux fondements de la végéphobie : l'importation de l'antispécisme en France}

Un collectif de passeurs à la marge du champ intellectuel

Les transferts opérés sont le fait d'un groupe restreint de militant $\cdot e \cdot s$ proches des milieux anarchistes, écologistes et alternatifs lyonnais (Dubreuil 2013). Issu.e.s de familles provenant pour l'essentiel des fractions culturelles de la bourgeoisie locale (enseignant.e.s du secondaire et du supérieur principalement), ces intellectuel.le.s et porte-paroles des squats et collectifs militants du quartier de la Croix-Rousse découvrent avec le mouvement de libération animale une nouvelle cause à développer. Refusant l'héritage parental, ils investissent l'espace public et le champ intellectuel par des voies différentes, l'engagement antispéciste constituant alors une modalité parmi d'autres pour se distinguer et affirmer as opposed to the monopoly of life scientists' right to speak about anything related to nature (Carrié 2015a). This enabled the mission of proponents of animal ethics, who henceforth found the first signs of their systemic criticism of animal exploitation in the writings of nineteenth- and early twentieth-century activists. The substantial resources mobilized by these agents along with the peculiarities of the national configurations they belonged to, were both conditions of the social success of the concepts that they produced and of the collective anti-speciesist mobilization which gained momentum from that point in the US and the UK. This was not at all the case when it came to the importation to France.

\section{The Founding Principles of Vegephobia: Importing Anti-Speciesism into France}

\section{A Group of Importers on the Fringes of the Intellectual Field}

The transfers that took place happened thanks to a small group of activists in Lyon with close ties to anarchist, environmentalist, and alternative circles (Dubreuil 2013). These intellectuals and spokespeople for squats and militant groups from the Croix-Rousse neighbourhood were generally from local bourgeois backgrounds (primarily families of teachers of secondary and higher education). They discovered a cause to develop in the animal liberation movement. Rejecting what they inherited from their parents, they entered the public arena and the intellectual field via alternative routes, the anti-speciesist involvement thus constituting one way of standing out and affirming heterodox intellectual positions. ${ }^{5}$

5 The story of Yves Bonnardel, a significant figure in French anti-speciesism, is exemplary in this regard. The son of a secondary school teacher who was 
des positions d'intellectuels hétérodoxes ${ }^{5}$. Les ressources dont ils disposent - notamment un volume important de capital culturel leur permettent entre la fin des années 1980 et le début des années 1990 de s'imposer comme les principaux promoteurs de ces conceptions. À cela s'ajoutent la socialisation transnationale et le bilinguisme français-anglais de l'un d'entre eux, David Olivier, qui va occuper une position centrale dans ce collectif de passeurs de sens ${ }^{6}$. Ainsi l'explique Yves Bonnardel, autre membre fondateur

du collectif :

D'abord c'est David qui a trouvé le texte La Libération animale, Animal Liberation en anglais, avant qu'il ne soit publié en français. Lui, il est bilingue, donc il avait accès assez aisément à la littérature anglophone ce qui n'est pas mon cas, en plus moi je venais idéologiquement de

5 La trajectoire d'Yves Bonnardel, figure importante de l'antispécisme français est à ce titre exemplaire. Fils d'un enseignant du secondaire très impliqué dans le mouvement maoïste, il a cherché à bricoler une voie alternative au modèle d'engagement paternel. II affirme ainsi dès son adolescence sa différence, en se revendiquant notamment de l'anarchisme individualiste, quitte très tôt l'école pour se former et vivre en communauté, puis s'investit dans des causes minoritaires : lutte contre la domination adulte dans un premier temps, qui se couple plus tard avec la promotion de la cause antispéciste.

6 David Olivier est né en 1956, d'une mère états-unienne hôtesse de l'air et d'un père français universitaire. Bilingue, il passe son enfance à Londres et pou partie à Sarajevo, avant d'emménager avec sa famille à Annecy en 1967. II réalise une scolarité brillante : en 1974 il obtient son baccalauréat ainsi que le deuxième prix du concours général de physique. II entre par la suite en classe préparatoire mathématiques à Lyon, puis à l'École normale supérieure de Saint-Cloud (il finit premier au concours d'entrée de 1976). Militant par ailleurs auprès des groupes libertaires et écologistes, il obtient un master en physique nucléaire et en physique des particules. Enseignant dans un premier temps la physique dans le secondaire, il quitte l'enseignement en 1983 pour un poste d'ingénieur informatique et a exercé depuis lors successivement à l'Université Lyon 3 puis Lyon 2 (données recueillies en entretien et sur son site personnel).
Their resources - in particular a large amount of cultural capital allowed them to assert themselves as the main proponents of these concepts at the end of the 1980s and the beginning of the 1990s. Added to this were the transnational socialization and the FrenchEnglish bilingualism of one among them, David Olivier, who played a central role in this group of ideological importers. ${ }^{6}$ Thus explains Yves Bonnardel, another founding member of the group:

David was first to discover Animal Liberation in English before it had been published in French. Being bilingual, he had easy access to English-language material, which was not the case for me; and I also came from an antisocial and anti-moral individualist ideology in the vein of Max Stirner.

heavily involved in the Maoist movement, he sought to forge an alternative path to his father's model of engagement. He thus affirmed his difference from his adolescence in particular by turning to individualist anarchism. He left school very early so that he could train and live in a community, before getting involved with minority causes: the fight against adult domination first of all, which he later complemented with his promotion of the anti-speciesist cause.

6 David Olivier was born in 1956 to an American air hostess mother and French academic father. He was bilingual, spending his childhood in London and partly in Sarajevo before emigrating with his family to Annecy in 1967. He was a brilliant student, passing his baccalauréat in 1974 and winning second prize in the concours général national competition for students in physics. He then began a classe préparatoire (post-baccalauréat training for France's grandes écoles) in mathematics in Lyon before attending the Saint-Cloud École normale supérieure (coming first in its entrance exam of 1976). Alongside campaigning libertarian and environmentalist groups, he obtained a master's in nuclear and particle physics. Having initially taught physics at secondary education level, he left teaching to take up a position as an IT engineer at the University of Lyon 3, and then at Lyon 2 (information gathered from an interview and from his personal site). 
l'individualisme anti-social et anti-moral à la Max Stirner. Ce qui fait que j'avais énormément de réticence vis-à-vis de toute approche morale... alors que David était déjà [...] dans ce cadre-là. Donc là, c'est [...] David qui a tiré dans ce sens-là et [...] j'ai mis des années à me sentir en accord avec cette approche. Je dirais que c'est vraiment David qui a introduit la politique morale en France ${ }^{7}$.

La fondation au début des années 1990 d'une revue, Les Cahiers antispécistes, dans laquelle ils traduisent et interviewent les principales figures du courant animaliste radical renouvelé (Karcher, Olivier, Vidal 1992), leur permet de faire valoir contre d'autres collectifs une définition de la notion d'antispécisme proche de celle développée par Singer (Bonnardel 1992 ; Olivier 1993). La mobilisation contre l'exploitation animale y est articulée aux luttes contre les discriminations sexistes ou racistes. Les antispécistes français se présentent ainsi comme instigateurs d'un nouveau mouvement égalitaire, prenant en compte l'ensemble des rapports de domination. Ils s'opposent en cela rapidement au groupe parisien constitué à la même époque Action information pour les droits des animaux (AIDA), qui prône un antispécisme apolitique et une stricte focalisation sur la problématique de l'exploitation

animale :

L'AIDA à l'époque, [...] on se disait « ah, ils sont à peu près sur la même longueur d'ondes ». Ils voulaient faire un groupe à Paris dans ce sens-là, donc on avait décidé de les soutenir. Et puis petit à petit on a su que derrière notre dos ils disaient pleins de méchancetés sur nous, comme quoi on serait des gauchistes. Alors, on était peut-être des gauchistes [...], mais on avait le droit de défendre nos positions. C'est-à-dire, si on veut que le terme animal ne soit

7 Entretien avec Yves Bonnardel, réalisé le 31 mai 2008.
This meant that I was incredibly reticent regarding any moral approach [...], whereas David was already [...] part of this way of thinking. So it was [...] David who was pulling in this direction and [...] it took me years to come round to this approach. I'd say it was really David who introduced moral politics into France. ${ }^{7}$

The creation at the start of the 1990s of Les Cahiers antispécistes journal, comprising translations of and interviews with the leading figures of the revived radical animal rights movement (Karcher, Olivier, Vidal 1992), allowed them to assert over other groups their definition of the notion of anti-speciesism, which was close to that developed by Singer (Bonnardel 1992; Olivier 1993). The movement against animal exploitation was linked to struggles against sexist and racist discrimination. The French anti-speciesists thus presented themselves as instigators of a new egalitarian movement which took all power relations into account. They therefore quickly distinguished themselves from the Parisian group formed at the same time, Action information pour les droits des animaux (AIDA), which promoted apolitical anti-speciesism with a strict focus on the issue of animal exploitation:

At the time we said about AIDA, "Oh, they're more or less on the same wavelength." They wanted to form a group in Paris along these lines, so we decided to support them. And then little by little we realized that they were saying lots of horrible things behind our backs - that we were leftists. Perhaps we were leftists then [...], but we had the right to defend our position. That's to say that if we wish the term animal to no longer be discriminatory, and we consider that

7 Interview with Yves Bonnardel, 31 May 2008. 
plus discriminatoire et que l'on considère que ce qui importe c'est d'être des êtres sensibles, donc les humains sont des animaux aussi et ce qui arrive aux humains ça nous importe aussi. [...] Et donc la politique humaine ça nous importe ${ }^{8}$.

\section{Une tentative de reproduction du coup double de Peter Singer}

Ce n'est alors pas principalement vers les organisations de la cause animaliste française existantes que ces importateur.rice.s se tournent pour diffuser les schèmes de la libération animale. II faut dire que les milieux militants animalistes cumulent des traits qui sont autant d'obstacles à la diffusion de ces concepts : faiblesse, voire inexistence des critiques systémiques et des traditions radicales de défense des animaux (les ligues antivivisectionnistes disparues au début du $X x^{e}$ siècle ne se reconstituent qu'à la fin des années 1950, et encore seulement sous l'impulsion d'organisations étrangères comme la British Union for the Abolition of Vivisection [Duranton de Magny 1980 : 5]) ; focalisation des principales associations comme la Société protectrice des animaux (SPA ${ }^{9}$ sur les animaux de compagnie et la gestion des refuges pour animaux errants $^{10}$; faible renouvellement générationnel des collectifs. Les organisations françaises de la cause animale revendiquent donc pour l'essentiel des critiques sectorielles de l'exploitation des bêtes

8 Entretien réalisé avec David Olivier, le 29 juin 2008

9 Fondée en 1845 et constituée sur le modèle de l'organisation britannique Royal Society for the Protection of Cruelty to Animals, la SPA est la première association de protection animale française à se pérenniser en France. Elle conserve au moins jusqu'au début $d u x^{e}$ siècle une position quasiment hégémonique.

10 Cette tendance déjà prégnante au début $d u x^{e}$ siècle s'accentue encore lorsque la SPA signe avec la préfecture de police de Paris le 4 juin 1960 une convention par laquelle l'association se voit déléguer la gestion de la fourrière municipale des animaux. Carton DB742 des archives de la préfecture de police de Paris. what matters is being sentient beings, then humans are animals too, and what happens to humans also matters to us. [...] And so human politics also matter to us. ${ }^{8}$

\section{Trying to Reproduce Peter Singer's "Double-Hit"}

It was not therefore primarily to existing French animal rights organizations that the importers turned to spread the idea of animal liberation. Animal activist circles in fact displayed characteristics that were as much obstacles to the spread of these concepts: weak or even non-existent systemic criticism and radical traditions of the defence of animals (anti-vivisectionist leagues which had disappeared at the beginning of the twentieth century, did not reappear until the end of the 1950s, and again only when prompted by foreign organizations such as the British Union for the Abolition of Vivisection [Duranton de Magny 1980: 5]); focus of the main associations such as the Sociéte protectrice des animaux (SPA) ${ }^{9}$ on pets and the management of refuges for stray animals; ${ }^{10}$ and weak generational renewal of groups. French organizations in support of animals essentially held industry-based criticisms of the exploitation of animals, and based their actions on moral values of goodness and charity, and on the condemnation of cruelty, and individual mistreatment. Furthermore, they had no relationship with

8 Interview with David Olivier, 29 June 2008.

9 Founded in 1845 and built on the model of the British organization Royal Society for the Protection of Cruelty to Animals, the SPA was the first animal protection society established in France. It retained an almost hegemonic position until the beginning of the twentieth century.

10 This trend, which was already strong at the beginning of the twentieth century, grew more pronounced when the SPA signed an agreement with the Paris Police Prefecture on 4 June 1960 that gave the association management of the municipal animal pound. File DB742 of the Paris Police Prefecture archives. 
et fondent leurs actions sur des valeurs morales de bonté et de charité, sur la condamnation des cruautés et des maltraitances individuelles. Par ailleurs, elles n'entretiennent aucune relation avec les associations de promotion du végétarisme, qui en France se focalisent alors de manière exclusive sur des problématiques thérapeutiques et n'abordent qu'à la marge la " question animale " (Ouédraogo 1994). Les quelques tentatives de promotion des considérations hétérodoxes portées par les antispécistes, et notamment du principe du végétarisme comme boycott des produits issus de l'exploitation des bêtes à viande, se heurtent dès lors à l'incompréhension et à l'hostilité des représentants des groupes établis de la protection animale en France. C'est ce qu'explique à nouveau Yves Bonnardel, se remémorant les premiers moments

de son engagement :

Quand on a commencé, il y avait peut-être un pour cent de végétariens dans la protection animale. C'était du délire, il n'y avait personne [...], on se faisait insulter et menacer [...]. Je me rappelle d'une cheffe d'association [...] qui disait à l'époque : «allez parler de végétarisme à mes fils, ce sera la porte ou la fenêtre ». Ils disaient : " les gens mangent ce qu'ils veulent, nous on se bat pour les animaux $» 11$.

Dans le sillage de Paola Cavalieri, journaliste qui contribue alors via la revue Etica \& Animali à faire connaître le mouvement de libération animale en Italie, les antispécistes français·es vont opposer à la « sensiblerie » de la protection animale, la rationalité et le sérieux des philosophes anglophones travaillant sur l'éthique animale. Contrairement à la publiciste italienne toutefois, ils et elles ne concentrent pas de manière exclusive leurs efforts et

11 Entretien avec Yves Bonnardel, réalisé le 31 mai 2008. associations that promoted vegetarianism, which at that time in France exclusively focused on health issues, scarcely dealing with "animal issues" (Ouédraogo 1994). The few attempts at promotion of the heterodox considerations raised by the anti-speciesists, and in particular the principle of vegetarianism as a means of boycotting products derived from animal exploitation for meat, henceforth met with incomprehension and hostility from the representatives of the French established groups for animal protection. As Yves Bonnardel explains again, remembering the early days of his engagement.

When we started, there was perhaps one per cent of those involved in animal protection who were vegetarian. It was crazy, there was no one [...], we were insulted and threatened [...]. I remember one of the heads of the association [...] who would say: "Go and talk about vegetarianism to my sons - you could either walk out the door or be thrown out the window." They said: "People can eat what they want; we're

fighting for animals." 11

After the example of Paola Cavalieri, a journalist who helped spread the word about the animal liberation movement in Italy via the Etica \& Animali magazine, French anti-speciesists countered the "sentimentality" of animal protection with the rationality and the seriousness of English-speaking philosophers working in the realm of animal ethics. However, unlike Cavalieri, they did not focus their efforts and work as importers exclusively on the academic sphere.

11 Interview with Yves Bonnardel, 31 May 2008. 
leurs activités de passeur.se-s vers les milieux académiques : intellectuel.le.s à la marge de ces espaces, inscrit.e.s par ailleurs dans des collectifs libertaires, ils et elles essaiment également vers ces groupes militants. Ils et elles tentent en quelque sorte de reproduire en France le « coup double » réussi de Peter Singer, en direction à la fois du mouvement social de l'époque et des milieux intellectuels et académiques.

On n'était pas très très chaud pour cette division entre êtres humains dont la vocation serait de penser et puis d'autres êtres humains dont la vocation serait de consommer des feuilletons télévisés. Et donc on a essayé de faire la synthèse entre les deux choses. Et Les Cahiers antispécistes est né de ça, [...] de l'idée de faire un petit peu ce que faisait la revue de Paola à Milan, c'est-à-dire traduire les textes du débat anglo-saxon. Et donc on a voulu faire ça pour essayer de commencer à les diffuser y compris dans les cercles de philosophie académique, puisque c'était des textes de philosophie, on voyait pas pourquoi en France ils ne seraient pas reçus comme des textes de philosophie. Et puis en même temps faire quelque chose qui soit au niveau militant, [...] du collage d'affiches, de la diffusion de tracts, et avoir un discours qui ne soit pas en rupture totale avec ce qui nous tenait le plus à cœur, c'est-à-dire l'antiracisme, l'antisexisme, les trucs contre

les discriminations, c'est-à-dire les questions d'égalité ${ }^{12}$.

Dès lors, les tentatives de transfert des principes du mouvement de libération animale se font non seulement en direction du microcosme des squats et de la mouvance anarchiste, mais aussi

du champ académique.

12 Entretien avec David Olivier, le 29 juin 2008.
These intellectuals, who were on the fringes of such spaces, as well as being committed to libertarian groups, were also drawn towards activist groups. They tried, to a certain extent, to reproduce Peter Singer's "double hit" in France - in terms of targeting both the social movement of the time and the intellectual and academic spheres:

We weren't keen on this division between humans whose vocation in life was to think and then other humans whose vocation was to consume soap operas. And so we tried to create a synthesis between the two things. Les Cahiers antispécistes was born out of that, [...] out of the idea of doing something similar to what Paola's magazine had done in Milan - ie, translate the texts of the US/UK debate. So we wanted to do that to try to begin to spread [these texts], including in academic philosophical circles; since they were philosophical texts, we didn't see why they wouldn't be received in France as philosophical texts. And then at the same time we wanted to do something at the activist level, [...] putting up posters, distributing leaflets, and having a debate that did not completely go against our core values - anti-racism, anti-sexism, things against discrimination, in other words issues of equality. ${ }^{12}$

Henceforth attempts to transfer the principles of the animal liberation movement were made primarily towards the microcosm of squats and the anarchist movement, but also towards the academic field.

12 Interview with David Olivier, 29 June 2008. 


\section{Obstacles et résistances à la diffusion de l'antispécisme}

Le bilan de ces mises en circulation est mitigé. Dans le champ académique et l'espace de concurrence des productions philosophiques, les militant·e.s se revendiquant de l'antispécisme se heurtent à d'importantes résistances. Celles-ci résultent de logiques plurielles et renvoient aux spécificités des positions occupées par les contradicteur-rice·s de l'antispécisme. Ainsi par exemple, les critiques formulées par Luc Ferry dans Le Nouvel Ordre écologique (1992) se conçoivent comme prolongement de ses textes écrits avec Alain Renaut dans les années 1980, dans lesquels étaient fustigées tout à la fois l'orthodoxie universitaire et une pensée labellisée comme « anti-humaniste ». Réfutation de l'universalisme, trouvant ses fondements dans ce courant soixante-huitard ainsi que dans un «pathos » propre aux années 1930, l'antispécisme remettrait en cause l'exclusivisme de la condition humaine et la pérennité d'un humanisme dont l'auteur s'est constitué en champion. La contestation par Ferry des formes contemporaines de la cause animale, et avec elle de certains courants de l'écologie, est donc largement structurée en fonction des enjeux de lutte locaux dans lesquels l'intellectuel est pris. Ce sont encore d'autres mécanismes qui expliquent le rejet de ces conceptions chez des universitaires comme Jacques Derrida ou Élisabeth de Fontenay. S'ils ont tous deux écrit sur la « question animale », interrogeant le statut des bêtes et des relations que les humains nouent avec elles, ils ont aussi critiqué le courant anglo-américain de l'éthique animale et les collectifs militants qui s'en revendiquent (Derrida 2006 ; Fontenay [de] 2008). Au principe de cette réception défavorable, on trouve l'opposition actualisée entre la philosophie analytique anglophone - dont la tendance à l'intellectualisme se manifesterait chez les tenants de l'éthique appliquée comme Singer - et le courant derridien de la déconstruction attaché au contraire à réfuter toute forme de

\section{Obstacles and Resistance to the Spread of Anti-Speciesism}

The outcome of this circulation was mixed. In the academic field and the space where philosophical productions are in competition, anti-speciesist activists met with considerable resistance. This had multiple origins, and was linked to the specific nature of the positions held by the detractors of anti-speciesism. Thus, for example, Luc Ferry's criticism in Le Nouvel Ordre écologique (1992) can be seen as an extension of the texts he wrote with Alain Renaut in the 1980s denouncing both academic orthodoxy and what they dubbed "anti-humanist" reasoning. For Ferry, antispeciesism had its foundations in the spirit of 1968 as well as in a "pathos" specific to the 1930s, and was a rebuttal of universalism. It called into question the exclusivity of the human condition and the continuing relevance of humanism, of which Ferry was something of a champion. Ferry's challenge of contemporary forms of the animal rights cause and also of certain ecological trends was therefore largely structured by the local struggles he was involved in. Other mechanisms explained the rejection of anti-speciesist ideas by academics such as Jacques Derrida and Elisabeth de Fontenay. While they both wrote about the "animal cause" and questioned the status of animals and the relations that humans forge with them, they also both criticized the American and British trend of animal ethics and activist groups who based their actions on it (Derrida 2006; Fontenay [de] 2008). Behind this unfavourable reception lay an updated version of the battle between analytical philosophy of the English-speaking world - whose intellectual leaning manifested itself in proponents of applied ethics such as Singer - and the trend of Derridean deconstruction linked in contrast to a rejection of all forms of logocentrism, including that defining relationships to animals (Fontenay [de] 2013; Lamont 1987). 
logocentrisme, y compris dans la définition des rapports avec les animaux (Fontenay [de] 2013 ; Lamont 1987).

Formulées selon des enjeux distincts, les attaques portées contre l'antispécisme depuis le champ intellectuel ont pu faire l'effet d'un rejet massif et unanime pour les passeur.se-s de l'antispécisme, situé·e.s aux marges de cet espace. Pour habituels que soient les réflexes protectionnistes des dynamiques d'importexport intellectuel (Bourdieu 2002), la violence des critiques, formulées depuis des positions variées du champ intellectuel, est ici particulièrement appuyée. Les opérations de marquage discriminantes laissant entendre le caractère antihumaniste, voire crypto-fasciste du mouvement de libération animale éclairent les logiques de cette opposition. Au contraire des pays anglophones, où a été légitimée dès la fin $\mathrm{du} \mathrm{XIX}^{\mathrm{e}}$ siècle l'idée d'une prise de parole « profane » au nom des bêtes - c'est-à-dire d'une alternative critique aux discours et aux savoirs des scientifiques le principe d'une représentation politique des animaux n'est jamais parvenu jusque-là à s'implanter dans l'espace public en France (Carrié 2015b). L'altérité des conceptions portées par les passeur.se's antispécistes explique de fait pour partie la force des résistances opposées par de nombreu.x.ses auteur.e.s à l'importation de ce mouvement et de ses mots d'ordre. Ceux-ci sont perçus comme incompatibles avec le principe devenu cardinal depuis la fin de la Seconde Guerre mondiale de la stricte unicité de l'espèce humaine (Stoczkowski 1999). Sont ainsi durablement disqualifiées les tentatives de ces passeur.se-s pour diffuser dans le champ les préceptes radicaux des théoricien-ne-s de l'éthique animale. Si les antispécistes ont ponctuellement répliqué dans leurs Cahiers ou dans des ouvrages publiés par la maison d'édition Tahin Party, à laquelle collabore Yves Bonnardel (HardouinFugier, Reus, Olivier 2002), ils et elles n'ont jamais disposé de
The various forms of attack against anti-speciesism from the intellectual field were perceived by the importers positioned on the margins of this space as a huge and unanimous rejection of anti-speciesism. This becomes all the more apparent if we consider the form and content of the positions taken. As common as protectionist reflexes in the dynamics of intellectual import and export are (Bourdieu 2002), the vehemence of the critical stands expressed from various positions within the intellectual field was particularly pronounced in this case. Discriminating efforts to brand the animal liberation movement as anti-humanist or even crypto-fascist in character, elucidate these logics of opposition. In contrast to countries of the English-speaking world, where the idea of a "lay" position in support of animals as an alternative criticism to scientific discourse and knowledge had been legitimized since the end of the nineteenth century, the principle of a political representation of animals had not up until that point taken hold in the public space in France (Carrié 2015b). The otherness of the anti-speciesist importers' ideas indeed partly explains the strength of the opposition of a great many writers to the importation of this movement and its slogans, which were seen as incompatible with the strict uniqueness of the human race which, since the end of the Second World War, had become a cardinal principle (Stoczkowski 1999). The importers' attempts in the field to spread the radical tenets of animal ethics theorists were thus persistently thwarted. Although the anti-speciesists periodically replied via the Cahiers or in works published by the Tahin Party publishing house - on which Yves Bonnardel collaborated (Hardouin-Fugier, Reus, Olivier 2002) - they never had enough resources to make their dissonant voices heard in the academic space. 
suffisamment de ressources pour imposer leurs voix dissonantes dans l'espace académique.

Le transfert en direction des milieux d'extrême gauche n'a guère été plus concluant. Au sein du mouvement anarchiste, de nombreux collectifs se créent pourtant à une échelle locale au début des années 1990. De même se déploient des projets éditoriaux intégrant ces nouveaux enjeux de luttes. Mais l'implantation des idées antivivisectionnistes reflue à partir du milieu de la décennie. Ce désengagement s'explique surtout par l'hostilité marquée d'une « orthodoxie » libertaire et, plus particulièrement, des membres de la Fédération anarchiste. Si ceux-ci acceptent les traditions végétariennes et naturiennes ${ }^{13}$ développées dans le milieu anarchiste français du début du $x x^{e}$ siècle (Baubérot 2013 ; Bochet 1993), ils et elles rejettent néanmoins un courant jugé trop proche de l'utilitarisme, école de pensée perçue comme expression du libéralisme politique et économique (Colson 2001). La légitimation des préceptes antispécistes est aussi compliquée du fait du décalage temporel entre le moment de leur formalisation intellectuelle dans les années 1970 et les tentatives de transfert en France au cours des années 1990. Le groupe des antispécistes, qui s'appuie entre autres sur les textes séminaux de Singer qu'ils ont contribué à traduire ${ }^{14}$, a ainsi souffert de l'image controversée que s'est forgée l'universitaire. Si en 1975 Peter Singer n'est encore qu'un nouvel entrant peu connu dans l'espace académique, il a depuis beaucoup produit, non seulement sur la « question

13 Constitué à l'initiative du dessinateur et militant anarchiste Émile Gravelle le groupe des naturiens libertaires prône un retour à l'état de nature, qui passe pour certains de ses membres comme Georges Butaud et Sophia Zaïkowska par l'adoption d'un régime végétarien, voire végétalien.

14 C'est notamment le cas de la traduction française de Animal Liberation, publié chez Grasset en 1993 (Singer 1991, 1993, 2000).
The change of direction towards the extreme left was scarcely more successful, even though many groups had formed at a local level within the anarchist movement at the beginning of the 1990s. Likewise, publishing initiatives had emerged that incorporated these new elements of the struggle. But, from the middle of the decade, the strength of anti-vivisectionist ideas dwindled. This disengagement can be explained above all by hostility influenced by a libertarian "orthodoxy" and, even more so, by members of the Anarchist Federation. While the latter accepted the vegetarian and naturist ${ }^{13}$ traditions developed in French anarchist circles beginning in the early twentieth century (Baubérot 2013; Bochet 1993), they rejected a trend they judged to be too close to utilitarianism - a school of thought perceived as an expression of political and economic liberalism (Colson 2001). The legitimization of the anti-speciesist precepts was also complicated by the time lag between the point of their intellectual formalization in the 1970s and the attempts at their transfer to France during the 1990s. The anti-speciesist group, which relied on, among other things, the seminal texts of Singer that they had helped to translate, ${ }^{14}$ also suffered on account of his controversial reputation. Although in 1975 Peter Singer was nothing more than a little-known newcomer in the academic space, he had since produced a great deal of material, not only

13 Formed on the initiative of the cartoonist and anarchist activist Emile Gravelle, the group of individualist naturists advocated a return to "nature," which was brought about for certain members such as Georges Butaud and Sophia Zaïkowska by adopting a vegetarian or vegan diet.

14 This was particularly the case for the French translation of Animal Liberation published by Grasset in 1993 (Singer 1991, 1993, 2000). 
animale » mais aussi dans le domaine de la bioéthique, où ses vues ont suscité d'importantes polémiques. Soucieux de promouvoir sa conception d'un utilitarisme voué à la maximisation des préférences, il a défendu la nécessité de l'euthanasie non volontaire de nouveau-nés, enfants et personnes handicapé $\cdot e \cdot s$ ou malades dans les cas où la somme des souffrances pour la personne et ses proches excéderait celle des plaisirs (Singer 1996). La carrière intellectuelle de Singer et ses engagements dans l'espace public dans les années 1990 affectent dès lors la réception de la libération animale et de l'antispécisme, quand bien même les passeur.se's français·es ne se réclament pas de ses vues sur ces thématiques.

Perçus comme des tenants d'une forme d'eugénisme, ils et elles rencontrent une forte opposition de la part de certains groupes antifascistes et anarchistes. L'acmé de ces tensions a lieu à l'occasion de la Deuxième rencontre intergalactique, organisée en Espagne durant l'été 1997. Une délégation d'antispécistes français·es venue présenter une motion autour de la « question animale » est prise à parti par des groupes d'antifascistes, heurtés par la présence de textes de Singer, sur la table tenue par les militant·e.s. S'ensuit un échange houleux, l'hostilité du personnel organisateur et d'une majorité du public entraînant finalement l'exclusion des antispécistes :

Derrière les tribunes, nous n'étions que peu tenu·e.s au courant par l'organisation. Nous n'étions pas protégéee.s du groupe d'Andreas à deux mètres de là, dont un des membres a esquissé une agression physique contre l'un de nous. Nous avions peur, nous étions tou·te's en pleurs ou à bout de nerfs. On venait de nous traiter de fascistes, on nous déniait la moindre possibilité de répondre, on avait braqué contre nous une foule prête à nous lyncher. (La manipulation verbale 1998) on animal rights but also in the domain of bioethics, where his views sparked significant controversy. Keen to promote his ideas of a utilitarianism based on the maximization of preferences, he defended the necessity of non-voluntary euthanasia of newborns, children, and the disabled and ill in cases where the sum of suffering for the individual and those around them outweighs their happiness (Singer 1996). Singer's intellectual career and his involvement in the public space in the 1990s henceforth affected the reception of animal liberation and anti-speciesism, even though the French importers did not back his views on these issues. Seen as proponents of a form of eugenics, they met with strong opposition on the part of certain antifascist and anarchist groups. The climax of these tensions was the occasion of the Deuxième rencontre intergalactique - an event held in Spain in the summer of 1997. A delegation of French anti-speciesists who had come to put forward a motion on animal rights was challenged by anti-fascist groups who objected to the presence of Singer's texts on their stand. A heated exchanged ensued, and the hostility of the organizing team and the majority of the public eventually led to the exclusion of the anti-speciesists:

Behind the platform we were scarcely kept informed by the organization. We weren't protected from Andreas'group two metres away, one of whose members had started physically attacking one of us. We were afraid, we were all in tears or on edge. They called us fascists and denied any opportunity to respond - a crowd turned against us and was ready to lynch us. (La manipulation verbale 1998) 
Cet incident, qui s'ajoute à d'autres survenus dans la même période ${ }^{15}$, signale la fermeture progressive des milieux libertaires et de la gauche radicale aux conceptions de ces passeur.se-s. Le coup double réussi de Peter Singer aux États-Unis et en GrandeBretagne s'avère ici impossible à reproduire. Outsiders aux ressources limitées, inscrit.e.s dans une configuration nationale où l'idée d'une représentation politique des bêtes n'a rien d'une évidence naturalisée, les antispécistes ne parviennent pas à imposer une position équivalente de porte-parole des animaux, à l'intersection des champs politique et académique. Ces échecs successifs et les nombreuses difficultés que suscitent les tentatives de transfert sont autant d'événements matriciels de la notion de végéphobie. Ces militant·e·s en ressortent convaincu·e.s d'avoir, sur le temps long de leur carrière d'importateur.rice.s, subi une oppression du fait de leur combat contre l'exploitation des bêtes.

\section{Politiser le désarroi et représenter les représentants : la fabrication de la végéphobie et de la veggie pride}

Les transformations de la cause animale française

La production de la notion de végéphobie et sa déclinaison dans le répertoire d'action animaliste sous la forme de la manifestation annuelle de la veggie pride ne peut se réduire à une réaction mécanique des antispécistes aux résistances suscitées par leur

15 Ainsi par exemple d'une déclaration de 1995 des animateurs de la radio libertaire dans laquelle étaient disqualifiées et interdites d'antenne, dans un même ensemble, les idées fascistes, antisémites et antispécistes (Olivier 2000). Ce principe de fonctionnement reprenait le principe du manda sur l'antispécisme adopté à l'occasion du $52^{\mathrm{e}}$ congrès de la Fédération anarchiste à Rouen en 1995 qui établissait qu'aucune publicité favorable aux thèses antispécistes ne pouvait être faite par la fédération.
This incident, one of several that occurred in the same period, ${ }^{15}$ signalled the gradual closure of the libertarian milieux and the radical left towards the ideas of these importers. Peter Singer's successful double-hit in the US and the UK proved impossible to reproduce here. Outsiders with limited resources who were part of a national context in which the political representation of animals was an alien concept, the anti-speciesists failed to enforce equivalent positions as critical animal advocates, at the intersection of the political and the academic field. These successive failures and the many difficulties that the transfer attempts triggered were just as formative with regard to the notion of vegephobia. Over the long term of their trajectories as importers, these activists emerged convinced that they had suffered an oppression as a result of their fight against the exploitation of animals.

\section{Politicizing Discontent and Representing the Representatives: The Creation of Vegephobia and Veggie Pride}

\section{Transforming French Animal Protection}

The production of the notion of vegephobia and its application within animal rights campaigning in the form of an annual Veggie Pride demonstration cannot be reduced to a mechanical response of anti-speciesists to the resistance towards their importation

15 Thus, for example, in 1995 presenters on a libertarian radio station made a statement which discredited and prohibited from broadcast, fascist, antiSemitic, and anti-speciesist ideas as one and the same group (Olivier 2000) Such an approach reflected the principle of the terms on anti-speciesism adopted on the occasion on the 52nd congress of the Anarchist Federation in Rouen in 1995, which declared that no publicity favourable to the antispeciesist theories would be allowed by the Federation. 
activité de passeur.se.s. Si dans ce moment de fermeture des espaces où ils tentent de diffuser ces conceptions, et alors que de nombreux sympathisants se désengagent de la cause, certain'e.s des intellectuel-le.s à l'origine de ces transferts développent les fondements d'une croisade morale au nom des végétarien.ne-s victimes du spécisme ambiant, c'est aussi parce que leur espace des possibles est en train de changer. Envisagés dans cette perspective, les concepts de végéphobie et de veggie pride se conçoivent tout autant comme des manifestations d'ajustement à des configurations pour partie redéfinies dans la période.

Se donnent en effet à voir à la fin des années 1990 d'importants bouleversements au sein de la protection animale française. Ces transformations sont dues pour l'essentiel au renouvellement générationnel des membres de ces groupes, à la création d'organisations comme One Voice ${ }^{16}$ ou la Welfarm-PMAF ${ }^{17}$ qui ouvrent de nouveaux fronts - telle la question de l'exploitation des animaux d'élevage - et s'inspirent directement des campagnes des groupes de Grande-Bretagne et des États-Unis. La cause animaliste voit aussi affluer des militant.e.s issu.e.s d'une petite et moyenne bourgeoisie culturelle (Dubreuil 2013), souvent adeptes du végétarisme et bien plus au fait que leurs aîné·e·s des développements contemporains de la cause animale dans les pays anglophones, du fait tout à la fois de l'implantation en France, dans la période, d'antennes d'une importante organisation états-unienne

16 One Voice se constitue en 1995 à la suite de la fusion de trois organisations animalistes. Se revendiquant du patronage de Théodore Monod et d'une conception spiritualiste de la cause animale, ce groupe entretient des liens avec le théologien britannique Andrew Linzey, une figure du courant anglo-américain de l'éthique animale, qui a fait traduire en français plusieurs de ses livres.

17 L'organisation créée en 1994 se consacre à la dénonciation des violences subies par les animaux d'élevage. Elle a été pensée sur le modèle d'une importante organisation britannique, Compassion in World Farming. attempts. While it is true that the spaces in which they had been trying to spread their ideas were closing, and that many supporters were disengaging from the cause, some of the intellectuals leading these transfers developed the foundations of a moral crusade on behalf of vegetarian victims of the prevailing speciesism because their options were changing. Viewed from this perspective, the concepts of vegephobia and veggie pride can also be understood as manifestations of an adjustment to configurations that were partially redefined in the period.

Indeed, significant upheaval within French animal protection emerged at the end of the 1990s. These transformations were essentially due to the generational renewal of members of these groups, and to the creation of organizations such as One Voice ${ }^{16}$ or Welfarm-PMAF, ${ }^{17}$ which opened up new fronts such as the issue of the exploitation of livestock, and were directly inspired by the campaigns of US and UK groups. The animal rights cause also saw an influx of activists from the middle and lower cultural bourgeoisie (Dubreuil 2013), who were often advocates of vegetarianism, and much more familiar with contemporary developments in animal rights in English-speaking countries than their elders, owing to both the introduction into France of branches of the leading US organization People for the Ethical Treatment of Animals (PETA) at the time, and the development of the internet and transnational

16 One Voice was founded in 1995 after the merger of three animal rights organizations. Under the patronage of Théodore Monod and a spiritualist approach to animal rights, this group maintained links to the British theologian Andrew Linzey, one of the figures of the animal ethics movement in the Englishspeaking world. Linzey had several of his books translated into French.

17 An organization created in 1994 to campaign against the abuse of farm animals. It was built on the model of a leading British organization, Compassion in World Farming. 
comme People for the Ethical Treatment of Animals (PETA), du développement d'Internet et de campagnes et supports militants

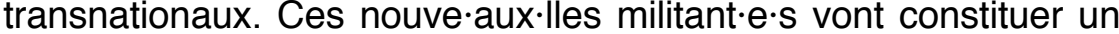
public privilégié et réceptif pour les pionnier-ère·s encore actif-ve·s de l'antispécisme français. Ceux et celles-ci dès lors réorientent en partie leur action, en direction de cet espace militant renouvelé. Ainsi en est-il de la constitution en 2001 de la veggie pride, la manifestation pour la fierté d'être végétarien·ne.s pour les droits des animaux, qui est conçue comme un moyen privilégié pour fédérer des militant·e.s épars, et dont le nombre ne cesse alors de croître :

La veggie pride, ça a ouvert, d'une part, à des gens qui venaient de partout et de nulle part et, d'autre part, aux gens du milieu animaliste. Sans qu'on s'en rende compte, il y a eu une évolution de fond au sein du milieu animaliste. Progressivement, les gens qui étaient végétarien-ne·s ont pris de l'importance, des gens qui se retrouvaient dans l'antispécisme aussi. Sans qu'on s'en rende compte, parce qu'on n'avait pas essayé de lutter [...]. Et en fait, [...] début des années 2000 ou fin des années 1990, on s'est rendu compte qu'à l'Alliance végétarienne il y avait plein d'antispécistes, enfin de gens qui découvraient l'antispécisme, à commencer par le président. Mais [c'est] pareil pour des organisations animalistes : la PMAF c'est un antispéciste, One Voice c'est un antispéciste. Des nouvelles associations étaient tenues par

des antispécistes sans avoir une politique antispéciste ${ }^{18}$.

\section{Mise en forme d'un nouveau concept}

La conjonction de cette évolution et de la fermeture des espaces vers lesquels avaient été entrepris initialement le transfert des

18 Entretien avec Yves Bonnardel, le 31 mai 2008. activist resources and campaigns. These new militants constituted a privileged and receptive public for the still-active pioneers of French anti-speciesism. The latter then partly redirected their activities towards this renewed activist space. This was true for the creation in 2001 of Veggie Pride, the demonstration for pride in being vegetarian, which was an ideal means of unifying activists who were far apart, but whose number was increasing at the time:

Veggie Pride appealed on the one hand to people from all over, and on the other hand to people from the animal rights camp. Without realizing it, an underlying change within the animal rights milieu had occurred. Gradually, vegetarians grew in importance, as did the anti-speciesists. Without realising, since we had not tried to fight [...]. And in fact [...], at the beginning of the 2000s or end of the 1990s, we realised that Alliance végétarienne was full of anti-speciesists, or people who were discovering anti-speciesism, beginning with its president. But it was the same for animal rights organizations: PMAF is anti-speciesist, One Voice is anti-speciesist. New associations were supported by anti-speciesists although they did not promote anti-speciesist policies. ${ }^{18}$

\section{Creation of a New Concept}

The convergence of this evolution and the closure of the spaces that the transfer of the animal liberation movement slogans had first

18 Interview with Yves Bonnardel, 31 May 2008. 
mots d'ordre du mouvement de libération animale, va être déterminante dans la formalisation par ces acteur.rice-s de la notion de végéphobie. Les nombreux déboires subis au cours de leurs carrières contrariées de passeur.se's pèsent ainsi lourd dans les ajustements qu'ils et elles opèrent alors. Les obstacles auxquels ils et elles se heurtent depuis la fin des années 1980 commandent l'adoption de stratégies obliques et la mise en œuvre de bricolages conceptuels. Au contraire des pays anglophones où l'idée d'une prise de parole critique au nom des bêtes est communément acceptée, les difficultés à se voir reconnaître en France comme leurs représentants légitimes entraînent une tentative de redéfinition partielle du porte-parolat. C'est ainsi que s'élabore la notion de végéphobie à l'orée des années 2000 et qu'est formulée l'idée par le biais de la veggie pride d'une représentation des représentant·e·s, de ces végétarien $\cdot n e \cdot s$ pour

les animaux subissant cette forme spécifique de discrimination :

Une manifestation pour exiger notre droit à la pleine reconnaissance sociale et à la pleine liberté d'expression en tant que personnes qui sommes solidaires des animaux, et donc ne les mangeons pas et estimons illégitime que quiconque les mange. Un schéma à double détente, en somme : par la veggie pride nous n'exigeons pas la fin du viandisme, mais exigeons de pouvoir l'exiger... Cela peut paraître une distinction subtile, mais je crois qu'elle est essentielle. C'est un peu la même différence qu'entre partager les idées d'une personne et défendre son droit à les exprimer. Cette distinction est en principe reconnue dans nos sociétés démocratiques. Nous pouvons dès à présent, au nom des principes mêmes de la démocratie et des droits humains, exiger non que l'on se plie à nos idées, mais que l'on admette pleinement notre droit à les exprimer au grand jour et à ce targeted were decisive in the formation of the notion of vegephobia by these actors. The many setbacks suffered over the course of their frustrated role as importers thus weighed heavily on the adjustments they then made. The obstacles that they had faced since the end of the 1980s led to the adoption of oblique strategies and the implementation of conceptual solutions. Unlike in the US and the UK, where the idea of a critical advocacy for animals was accepted, the difficulties in gaining recognition in France as legitimate representatives brought about a partial attempt at redefinition of the idea of representation. The notion of vegephobia developed in the same way at the start of the 2000s, and likewise the ideas formed, thanks to Veggie Pride, of a representation of the representatives - these vegetarians for animal rights - who suffer a specific form of discrimination:

A demonstration to demand our right to full social recognition and full freedom of expression as people who are in solidarity with animals, and therefore do not eat them, and do not believe that anyone should eat them. A two-pronged approach, in essence: Veggie Pride does not demand an end to eating meat, but rather the power to demand this [...]. This may appear a subtle distinction, but I think it's essential. It's a bit like the difference between sharing someone's ideas and defending their right to express them. This distinction is recognized in principle in our democratic societies. We can now, in the name of the same principles of democracy and human rights, demand not that all must conform to our ideas, but that our right to express them openly be fully acknowledged, and that they be taken seriously and not pushed aside and maligned from the outset. (Olivier 2001) 
qu'elles soient prises en compte avec sérieux, et non écartées et diffamées d'emblée. (Olivier 2001)

Encore faut-il donner de la consistance et de la chair à cette notion de végéphobie, qui doit légitimer la prise de parole des végétarien·ne·s qui la subiraient. Pour ce faire, les initiateur.rice-s de ces novations conceptuelles vont entamer un travail de collecte de témoignages glanés auprès des participant·e.s de la veggie pride ou sur les sites et forums de discussion végétariens et/ou vegans ${ }^{19}$. Vexations des proches à l'encontre d'un régime alimentaire, stigmatisations publiques de pratiques de consommation, édiction de décrets qui interdisent les repas végétariens et végétaliens dans la restauration collective $^{20}$ : c'est tout un ensemble de comportements et de représentations faisant système que cherchent à mettre au jour les militant·e·s. L'épaisse brochure La Végéphobie ou le rejet du végétarisme pour les animaux et la discrimination des personnes végétariennes, publiée en 2011 dans le cadre d'une campagne de promotion du concept menée entre autres par Yves Bonnardel, recense ainsi des expressions variées de la végéphobie : les moqueries (qui nient la possibilité du végétarisme ou qui louent le goût de la viande par exemple), le déni (la dénégation notamment de la possibilité d'adopter un régime végétarien), les discriminations subies auprès des médecins et du fait de la politique de santé

19 Cf. le site vegephobia.info, qui recense et concentre un ensemble de témoignages sur les expressions supposées de végéphobie.

20 En cause ici un décret et un arrêté du 30 septembre 2011 relatifs à la qualité nutritionnelle des repas servis dans le cadre de la restauration scolaire et qui instaurent l'obligation de servir régulièrement de la viande et du poisson. En réaction à l'édiction de ces textes est initiée une mobilisation, portée entre autres par David Olivier. Toujours sous l'impulsion du même groupe est déposé auprès du rapporteur spécial des Nations unies sur la liberté de religion ou de conviction un dossier dénonçant la végéphobie en France. Cf. le site de l'initiative citoyenne pour le droit des végétariens.
But they needed to give this notion of vegephobia consistency and flesh - to encourage vegetarians who suffer it to speak out. To do this, the initiators of these new ideas began the task of collecting testimonies gleaned from participants of Veggie Pride or from vegetarian and/or vegan discussion sites and forums. ${ }^{19}$ Harassment from relatives when they find out about a diet, public stigma surrounding consumption practices, and the enactment of decrees forbidding vegetarian and vegan meals in mass catering ${ }^{20}$ are all types of systematic behaviour and representations the activists seek to expose. The thick booklet entitled La Végéphobie ou le rejet du végétarisme pour les animaux et la discrimination des personnes végétariennes (Vegephobia or the Rejection of Vegetarianism for Animals and the Discrimination of Vegetarians), published in 2011 as part of a campaign led by Yves Bonnardel among others to promote the concept, listed different expressions of vegephobia: mockery (denying the possibility of vegetarianism or praising the taste of meat, for example); denial (particularly of the possibility of adopting a vegetarian diet); discrimination by doctors and as a result of French public health policies; or difficulties encountered by vegetarian parents regarding acceptance by the

$19 C f$. the Vegephobia site, which compiles testimonies of apparent expressions of vegephobia.

20 This relates to a decree and order of 30 September 2011 regarding the nutritional quality of school meals, which implemented the obligation to serve meat and fish regularly. The enactment of these texts initiated a protest led by David Olivier, among others. The same group delivered a file denouncing vegephobia in France to the United Nations Special Rapporteur on Freedom of Religion or Belief. Cf. the Initiative citoyenne pour les droits des végétariens (Citizens' Initiative for vegetarian rights) site. 


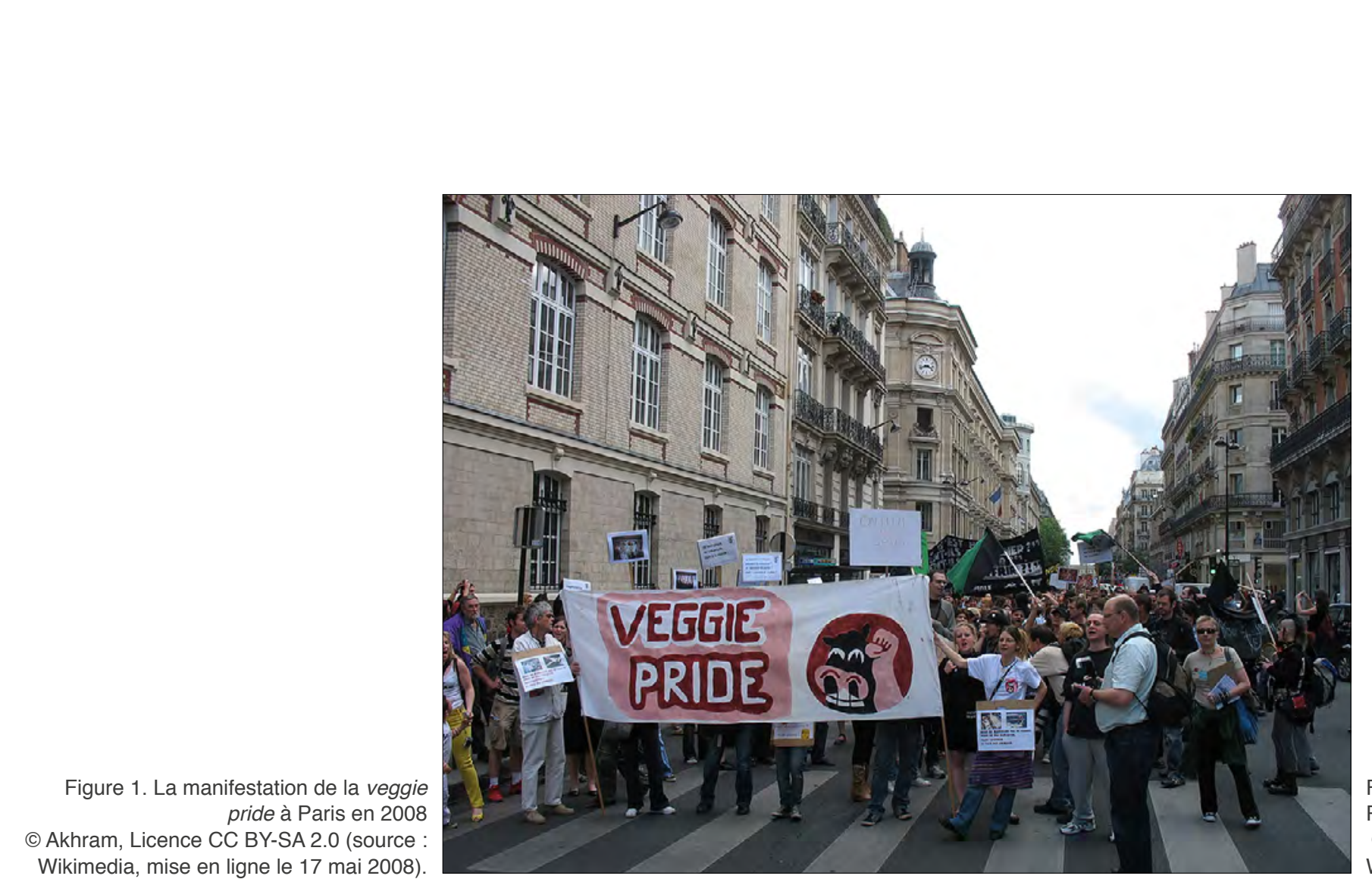

publique française, ou encore les difficultés rencontrées par les parents végétariens pour faire accepter auprès de l'Éducation nationale et de l'administration les pratiques alimentaires de leurs familles (Bonnardel, Fergé, Olivier 2011).

S'il ne nous appartient pas de statuer sur la réalité de cette forme de stigmatisation, toujours est-il que la végéphobie est confortée, selon ses promoteur.rice.s, par les expériences passées des pionnier-ère-s et passeur.se.s français de l'antispécisme encore engagé e.s. Pour ces dernier-ère $\cdot s$, la notion fournit sens et signification aux résistances rencontrées dans leurs activités d'importateur.rice·s : ces résistances apparaissent comme des national education system and the authorities of their family's dietary choices (Bonnardel, Fergé, Olivier 2011).

While it is not up to us to decide on the reality of this form of stigmatization, the fact remains that vegephobia is underpinned, according to its proponents, by the experiences of those French pioneers and importers of anti-speciesism who are still involved. The notion gave meaning to the resistance encountered in their activity as importers: this resistance appeared to be manifestations 
manifestations de végéphobie et d'une forme latente de défense du spécisme, dont eux-mêmes deviennent dès lors des victimes indirectes.

Si on dit qu'on veut que les intérêts des animaux soient pris en compte, on nous accuse d'être des anti-humains, [...] des émules d'Hitler parce qu'Hitler traitait les juifs comme des animaux. [...] Et ça c'est quelque chose qui est à mon avis réactif. [...] Les gens sentent bien que la question animale ça remet en cause beaucoup de choses au niveau idéologique, culturel, économique [...]. Et les gens prennent peur de ça et donc eux-mêmes se forcent à être ultra réactionnaires. [...] On va mettre le doigt dans des problèmes qui sont des problèmes complexes, sur lesquels on a voulu jeter une espèce de chape de plomb pour ne pas avoir à en parler. Parce qu'en parler c'était remettre en cause cette espèce d'identification extrêmement artificielle « nous on est les bons et les autres sont des méchants ». [...] Parce qu'on met en question la frontière humain-animal, on va [...] nous dire qu'on est comme des nazis, parce que les nazis traitaient les humains comme des animaux. Donc les gens réagissent de façon très violente par rapport à ça, parce qu'eux-mêmes se sentent très incertains ${ }^{21}$.

La végéphobie au final donne un surcroit de cohérence à des carrières militantes pourtant marquées par les ruptures et les réajustements (Bourdieu 1986). Des intellectuel-le·s dominé·e·s

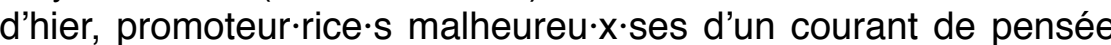
hétérodoxe aux militant.e.s et animateur.rice.s d'une cause animale rénovée d'aujourd'hui, il s'est toujours agi pour ces agent·e.s de dénoncer un même système généralisé d'oppression.

21 Entretien avec David Olivier, le 29 juin 2008. of vegephobia and of a latent form of defence of speciesism, of which they themselves soon became indirect victims.

If we say that we want animal rights to be taken into account, we're accused of being anti-human, [...] disciples of Hitler because Hitler treated the Jews like animals. [...] And that, in my opinion, is a reactive response. [...] People understand that animal rights call many things into question on an ideological, cultural, and economic level [...]. And people are afraid of that and so force themselves to be ultra-reactionary. [...] We're meddling in problems that are complex, which people have tried to ignore so as to not have to talk about them. Because talking about them calls into question this kind of extremely artificial identification of "we're the goodies and they're the baddies." [...] Since we're questioning the divide between humans and animals, people [...] say we're like Nazis, because the Nazis treated humans like animals. So people react very strongly to that, because they feel very uncertain themselves. ${ }^{21}$

Vegephobia finally gives extra coherence to activist careers which are marked by ruptures and readjustments (Bourdieu 1986). For yesterday's dominated intellectuals - the unfortunate promoters of a heterodox school of thought - as well as for the activists and leaders of a renewed animal rights cause - it has always been a case of denouncing the same widespread system of oppression.

21 Interview with David Olivier, 29 June 2008. 


\section{Politiser et représenter le collectif des végétariens}

La référence explicite et directe dans les termes forgés de végéphobie et de veggie pride aux luttes pour la reconnaissance des droits des homosexuel.le's met par ailleurs en lumière les enjeux de ces constructions intellectuelles. II s'agit de faire advenir à l'existence publique un groupe qui s'ignore, d'affirmer un « idéal du nous » (Bourdieu 1984 ; Elias \& Scotson 1997 ; Chartier 2013) des végétarien·ne·s, végétalien·ne·s et vegans en lutte contre la domination spéciste, cette prise de parole au nom des porteparoles devant se substituer pour partie à la représentation politique des animaux dont les pionnier.ère's antispécistes français·es ont éprouvé l'impraticabilité. En définitive, s'observe ici comme un glissement dans la structuration de l'idée de représentation politique des bêtes. L'impossibilité à faire reconnaître en France le principe d'une représentation-mandat critique des animaux, d'une prise de parole au nom de leur intérêt supposé à ne pas subir l'oppression humaine, amène ces passeur.se.s contrarié.e.s des novations conceptuelles inspirées de ce qui s'est fait en GrandeBretagne et aux États-Unis, visant à actualiser la définition du porte-parolat. II ne s'agit alors plus seulement de parler « au nom de », mais aussi de parler « en tant que ». Les végétarien·ne·s, végétalien.ne.s et vegans pour le droit des animaux soumis à la végéphobie ambiante seraient ainsi également les victimes victimes indirectes certes, mais victimes tout de même - du système spéciste, cette requalification devant leur permettre de justifier leurs revendications dans l'espace public. Parce que la représentationmandat des bêtes n'est pas naturalisée et neutralisée comme dans les espaces culturels anglo-américains, les antispécistes proposent ainsi d'y articuler les fondements d'une représentation-incarnation, en tant qu'ils s'incluent eux-mêmes dans le groupe des victimes de l'oppression qu'ils combattent (Hoffmann 2003 ; Sintomer 2013) :

\section{Politicizing and Representing the Vegetarian Collective.}

The explicit and direct reference to the battle for the recognition of gay rights in the terms of vegephobia and veggie pride, sheds further light on the concerns of these intellectual constructions. The aim is to achieve existence as a collective (Bourdieu 1984; Elias \& Scotson 1997; Chartier 2013) in the fight against speciesist domination. This case of the spokespeople speaking on their own account partly replaces the political representation of animals of which the French anti-speciesist pioneers experienced the impracticability. Ultimately, what we observe here is a structural shift in the idea of the political representation of animals. The impossibility of gaining recognition in France of the principle of a critical political representation of animals, and of an advocacy in their supposed interest of not suffering human oppression, led these frustrated importers of conceptual innovations of the Englishspeaking world to update the definition of advocacy itself. It is no longer only a case of speaking "on behalf of," but also "as." Vegetarian and vegan supporters of animal rights subjected to the prevailing vegephobia thus also become victims - indirect victims, to be sure, but victims all the same - of the speciesist system; this reclassification is expected to allow them to justify their claims in the public space. Because the political representation of animals is not accepted as it is in English-speaking cultural spaces, the anti-speciesists thus propose to articulate the foundations of an embodiment-representation, as far as they are themselves included in the group of victims of the oppression they are fighting (Hofmann 2003; Sintomer 2013): 
Quand nous dénonçons la végéphobie, ce n'est pas dans le seul but de montrer à quel point nous, les végétarien·ne·s, nous sommes discriminé·e.s. C'est bien pour montrer à quel point les animaux sont discriminés, même à travers nous. II faut garder à l'esprit que nous attaquer, c'est attaquer l'avocat pour atteindre le futur condamné. [...] Les animaux sont considérés comme inférieurs aux humains. En affichant notre solidarité avec eux, nous endossons cette infériorité, nous sommes dans une certaine mesure méprisé·e·s et marginalisé·e.s. Comme si, parce que nous disons que notre espèce n'a pas tous les droits, nous nous retrouvions déchu·e.s des privilèges que nous avions en naissant humains. Nous n'atteignons pas le degré d'injustice avec lequel sont traités les animaux (nous appartenons quand même à l'espèce dominante). Cependant, nous sommes clairement mis·es de côté, banni·e.s symboliquement.

$$
\text { (Bonnardel, Fergé, Olivier } 2011 \text { : 7-8) }
$$

La concordance est frappante entre ces formalisations nouvelles et les ruptures dans les trajectoires des antispécistes : ceux et cellesci renoncent alors à des positions de passeur.se.s impossibles à tenir pour recentrer leurs efforts en direction du milieu animaliste français. La découverte et la dénonciation de la végéphobie, l'affirmation du fait que les militant·e.s sont eux aussi des êtres sensibles confrontés à l'iniquité du spécisme, surviennent dans un moment de repli de ces importateur-rice-s vis-à-vis du champ académique, de reconversion de leurs dispositions scholastiques dans un espace militant jusque-là négligé. D'où l'affirmation d'un mode d'action comme la veggie pride, fondée non plus uniquement sur la froide raison et des arguments intellectuels, mais sur l'expérience sensible partagée par les végétarien·ne·s, sorte de plus petit dénominateur commun faisant écho aux obstacles rencontrés dans le passé par ces courtier-ère·s contrarié·e.s du courant de pensée de l'éthique animale (Roueff 2013). Les notions et mots d'ordre ainsi constitués se lisent donc aussi comme des tentatives d'universalisation des carrières malheureuses des antispécistes,
When we denounce vegephobia, it is not only to show the extent to which we, vegetarians, are discriminated against. It is to show the extent to which animals are discriminated against - even through us. It's important to keep in mind that to attack us is like attacking the lawyer to reach the convict. [...] Animals are seen as inferior to humans. By showing our solidarity with them we assume this inferiority - we are to some extent scorned and marginalized. As if, because we say that our species does not have all the rights, we find ourselves deprived of the privileges we had in being born human. We do not reach the degree of injustice with which animals are treated (we still belong to the dominant species). However, we are clearly shunned - symbolically banished. (Bonnardel, Fergé, Olivier 2011: 7-8)

The correlation between these new formalisations and the ruptures in the trajectories of the anti-speciesists is striking: the latter then gave up their impossible-to-maintain positions as importers to recentre their efforts in the direction of the French animal rights scene. The discovery and the denunciation of vegephobia, and the activists' assertion of the fact that they too were sentient beings who faced the injustice of speciesism occurred at a phase of withdrawal for the importers regarding the academic field, and of reconversion of their scholastic dispositions in a hitherto neglected militant space. Hence the assertion of a strategy such as "veggie pride," founded not only on cold reasoning and intellectual arguments, but on the real experiences shared by vegetarians - a kind of lowest common denominator echoing the obstacles encountered in the past by these frustrated thought-brokers of animal ethics (Roueff 2014). The concepts and slogans thus formed can therefore also be 
en vue de politiser des pratiques alimentaires et des modes de consommation jusque-là conçus pour l'essentiel comme extérieurs à l'ordre politique (Lagroye 2003 ; Aït-Aoudia, Bennani-Chraïbi, Contamin 2010). Le processus de politisation toutefois n'advient pas sans difficulté : si la veggie pride n'a cessé de prendre de l'ampleur depuis son lancement en 2001, du fait qu'elle constitue la seule manifestation unitaire de la cause animale en France, la notion de végéphobie n'a jusque-là que peu essaimé ${ }^{22}$. Elle reste largement confidentielle et suscite des résistances de la part des militant $\cdot e \cdot s$ animalistes, et ce jusque dans les espaces dédiés à sa promotion.

Il faut souligner, en dernier lieu, que ce processus de politisation du végétarisme initié à l'orée des années 2000 renvoie également à des considérations stratégiques et à des enjeux de luttes internes au mouvement animaliste français. Les pionnier $\cdot e ̀ r e \cdot s$ antispécistes subissent en effet depuis quelques années la concurrence d'acteur.rice.s et de groupes se réclamant d'une tendance jugée aux antipodes de leurs conceptions. Animé et représenté entre autres par le juriste Gary Francione (Francione 1996), ce courant états-unien qualifié d'abolitionniste considère la promotion et la généralisation des pratiques de consommation et du mode de vie vegan comme la seule stratégie viable pour mettre un terme à l'exploitation des animaux. Ses partisan·e·s récusent tout autre type d'initiative comme renforçant indirectement la domination des êtres humains sur les bêtes (Francione 1998). Les promoteur·rice·s

22 Voir encadré. La diffusion du terme est également limitée à l'étranger et n'est mobilisée que dans certains groupes militants suisses et italiens proches des antispécistes français. De même, on ne trouve que peu de références à la végéphobie dans la riche littérature anglo-américaine consacrée à la "question animale », malgré sa proximité avec les thèses de certaines intellectuelles proches de l'écoféminisme comme Carol J. Adams ou Marti Kheel (Adams 1990 ; Kheel 2004 ; Cole \& Morgan 2011). read as an attempt to universalize the unsuccessful trajectories of the anti-speciesists, with a view to politicizing food practices and consumption patterns perceived until then as being essentially outside the political order (Lagroye 2003; Aït-Aoudia, BennaniChraïbi, Contamin 2010). However, the process of politicization did not come about easily: while "veggie pride" had not ceased to grow since its launch in 2001, thanks to the fact it was the only unitary animal rights demonstration in France, the concept of vegephobia had up until then hardly spread. ${ }^{22}$ It mostly remained restricted and provoked resistance from animal rights activists, even in the spaces dedicated to its promotion.

It must be stressed, lastly, that this process of politicizing vegephobia that began at the start of the 2000s was also linked to strategic considerations and issues surrounding internal battles of the French animal rights movement. For several years, the antispeciesist pioneers had in fact faced competition from actors and groups supporting a trend that was considered to be the complete opposite of their ideas. Led and represented by, among others, the lawyer Gary Francione (Francione 1996), this American school of thought that was considered to be abolitionist, viewed the promotion and spread of vegan consumption practices and vegan way of life to be the only viable strategy to end the exploitation of animals. Its supporters refuted all other types of initiative as indirectly strengthening the domination of human beings over animals (Francione 1998). The promoters of Veggie Pride criticized

22 See boxed text. The spread of the term was similarly limited in other countries - only employed by certain Swiss and Italian activist groups close to the French anti-speciesists. Similarly, we only find a few references to vegephobia within the plentiful English-language literature on anima rights, despite its proximity to the theories of certain intellectuals linked to ecofeminism such as Carol J. Adams and Marti Kheel (Adams 1990; Kheel 2004; Cole \& Morgan 2011) 
de la veggie pride reprochent aux abolitionnistes de faire reposer leur stratégie sur la seule conversion personnelle au véganisme, et donc de dépolitiser celui-ci : ils et elles lui opposent leur définition d'un végétarisme politique, subversif et revendicatif, révélateur de

l'ampleur du système spéciste :

On peut être végétarien et cesser d'inviter les gens à suivre notre choix, pour plutôt dénoncer le massacre des animaux, et demander qu'il y soit mis fin. Manifester pour la fierté végétarienne, c'est aussi affirmer courageusement sa volonté de porter au centre du débat public la question animaliste, sans l'enrober et la camoufler dans la propagande en faveur du style de vie végan, sans en tempérer la protestation en la rendant plus rassurante et légère car limitée au comportement personnel. (Corabi 2009)

\section{La difficile adoption d'un concept en milieu militant.}

Extrait du carnet d'enquête, à l'occasion des Estivales de la question animale des 25 et 26 juillet 2012.

Compte-rendu de la séance « Proposition d'outils et d'exercices collectifs pour militer contre le spécisme (décharge émotionnelle, groupes de conscience, théâtre-forum) » organisée par Yves Bonnardel. Celle-ci est en fait centrée sur la notion de végéphobie, que Bonnardel et d'autres militant·e.s tentent à nouveau de promouvoir dans le milieu militant depuis quelques mois. II y a eu au préalable au moins une autre séance consacrée à la « végéphobie ", un exposé et une définition de ce dont il s'agissait, avec des exemples donnés des situations dans lesquelles cette forme de discrimination se donnerait à voir

Yves Bonnardel organise des groupes de trois ou quatre personnes, qui doivent se raconter leurs histoires les plus marquantes de végéphobie. Le concept n'est alors ni contesté, ni même questionné. Pendant le tour de table qui suit, où chacun revient sur ses expériences marquantes de la végéphobie, le the abolitionists for hinging their strategy on personal conversion to veganism alone, and therefore depoliticizing it: they contrasted this with their definition of a political vegetarianism, which is subversive, assertive, and revealing of the breadth of the speciesist system:

It's possible to be vegetarian and stop inviting people to follow our choice, and to instead denounce the slaughter of animals, and ask for this to end. To demonstrate in support of vegetarian pride is also to state courageously your willingness to bring animal rights to the centre of the public debate without masking or camouflaging it in propaganda in favour of the vegan lifestyle, without tempering the protest by making it lighter or more reassuring by restricting it to personal behaviour. (Corabi 2009)

The difficult acceptance of a concept in the activist milieu.

Extract from fieldwork notebook from the Estivales de la question animale, July 25th-26th 2012.

"Report of the session on 'A proposal of tools and collective action in the campaign against speciesism (emotional release, awareness-raising groups, theatre-forums, etc.)' organized by Yves Bonnardel. The session is in fact centred around the notion of vegephobia, which Bonnardel and other activists had been attempting to promote once again to activists for several months. There has been at least one other session on 'vegephobia' - a presentation and definition of what it was, with examples of situations in which this form of discrimination is displayed.

Yves Bonnardel organizes groups of three or four people who had to tell each other their most significant experiences of vegephobia. The concept is not challenged or even questioned. During the ensuing discussion, in which each participant goes over their memorable experiences of vegephobia, the concept seems to have 
travail d'acceptation du concept semble avoir fonctionné : la notion, qui était encore discutée un an auparavant dans les échanges informels entre militant·e.s, semble s'imposer comme une évidence.

La séance se poursuit sans difficulté, chacun apportant son témoignage des discriminations vécues, jusqu'à ce que l'une des dernières militantes à prendre la parole ne récuse le concept. Elle explique qu'elle voudrait plutôt revenir aux animaux, parler des stratégies à mettre en œuvre pour leur venir en aide (c'est l'argument d'autorité par excellence au sein de la cause). Des militant·e.s répliquent et défendent le principe de la séance, reprenant pour ce faire les arguments présentés initialement par Bonnardel (sans que celui-ci n'intervienne). Mais cette voix dissonante libère les inhibitions : des militantes expliquent qu'elles n'ont pas osé contredire les autres participants auparavant, mais qu'elles ne voient pas non plus l'intérêt de l'exercice, qu'elles qualifient d'auto-apitoiement.

\section{Conclusion}

II est difficile aujourd'hui de prédire l'issue de ces conflits internes à la cause, ou encore de statuer sur l'importance de ces querelles pour l'avenir du mouvement. Toujours est-il que les antispécistes français es mobilisent désormais leur expérience malheureuse d'importation des schèmes de la libération animale afin de résister à cette nouvelle vague de transfert venue des pays anglophones (Francione 2016). En suivant ainsi la carrière et la trajectoire des concepts et mots d'ordre militants, leur circulation à la fois transnationale et infranationale d'un espace de réception à l'autre, il est possible d'appréhender les logiques au principe du développement de traditions politiques et militantes nationales spécifiques, comme on le voit avec cette entreprise de représentation des représentant·e.s végétarien'ne.s des animaux, née du désarroi suscité par l'importation malheureuse d'un courant de pensée étranger. Si celle-ci constitue sans doute un cas limite, on espère avoir montré par son biais l'intérêt d'une démarche been accepted: though it was still discussed last year in informal exchanges between activists, the notion seems to be self-evident.

The session proceeds smoothly - each participant giving their testimony of the discrimination they had experienced until one of the last to speak rejects the concept. She explains that she would rather return to the subject of animals and talk about the implementation of strategies to help them (this being the argument par excellence within the cause). The activists reply and defend the principle of the meeting, taking up arguments originally presented by Bonnardel (without him intervening). But this dissonant voice frees inhibitions: other female activists explain that they had not dared contradict the other participants before, but that they don't see the point of the exercise either, which they regard as self-pitying."

\section{Conclusion}

It is difficult today to predict the outcome of these internal conflicts within the cause, or to qualify the importance of these disputes for the future of the movement. It is still the case today that French antispeciesists refer back to their unfortunate experience of importing ideas about animal liberation in order to resist this new wave of transfer from English-speaking countries (Francione 2016). By following the progress and trajectory of activist concepts and slogans in this way, their transnational and subnational circulation from one space of reception to another, it is possible to comprehend the logics underpinning the development of specific national political traditions and protests, as we can see with this endeavour to represent vegetarian animal representatives, born out of the discontent caused by the unsuccessful importation of a foreign school of thought. While this undoubtedly constitutes an extreme example, I hope to have demonstrated through it the relevance of an approach that articulates findings in the social history of political 
articulant les attendus de l'histoire sociale des idées politiques et de l'analyse des mouvements sociaux, considérés comme des entreprises culturelles productives de biens symboliques. Peuvent ainsi s'apprécier les transformations en acte des porte-parolats, ainsi que les modalités de bricolages conceptuels jamais figés, sensibles aussi bien aux évolutions des contextes et des rapports de force à un niveau macro- et méso-social, qu'aux bouleversements et ruptures des biographies individuelles.

$\begin{array}{ll}\text { Fabien Carrie } & \text { Institut des sciences sociales du politique (ISP - CNRS) }\end{array}$

\section{Références bibliographiques}

Adams Carol (2016). La Politique sexuelle de la viande : une théorie critique féministe végétarienne. Traduit par Danielle Petitclerc. Lausanne, L'Âge d'homme.

AïT-Aoudia Myriam, Bennani-ChraïBI Mounia, Contamin Jean-Gabriel (2010). " Contribution à une histoire sociale de la conception lagroyenne de la politisation ». Critique internationale, 48(3) : 207-220.

BAUBEROT Arnaud (2013). "Les naturiens libertaires ou le retour à l'anarchisme préhistorique ». Mil neuf cent. Revue d'histoire intellectuelle, 31(1) : 117-136.

Belorgey Nicolas, Chateignier Frédéric, Hauchecorne Mathieu, PÉNISSAT Étienne. "Théories en milieu militant. Introduction 》. Sociétés contemporaines, $81: 5-25$.

BENTHAM Jeremy (2011) [1789]. Introduction aux principes de morale et de législation. Traduit par le Centre Bentham (France). Paris,Vrin.

BOCHET François (1993). « Naturiens, végétariens, végétaliens et crudivégétaliens dans le mouvement anarchiste français (1895-1938) ». ideas and in analysis of social movements, which are considered to be cultural enterprises producing symbolic goods. This approach also makes it possible to appreciate practical transformations of advocacy, and of a conceptual bricolage which consists in using methods that remain fluid and as susceptible to evolutions of contexts and power relations on a macro and meso social level, as to the upheavals and ruptures of individual biographies.

Fabien Carrié

Institut des sciences sociales du politique (ISP - CNRS)

\section{References}

Adams Carol (1990). The Sexual Politics of Meat: a Feminist-Vegetarian Critical Theory. New York, Continuum.

Aït-Aoudia Myriam, Bennani-Chraïbı Mounia, Contamin Jean-Gabriel (2010). "Contribution à une histoire sociale de la conception lagroyenne de la politisation." Critique internationale, 48(3): 207-220.

BAUBÉROT Arnaud (2013). "Les naturiens libertaires ou le retour à l'anarchisme préhistorique." Mil neuf cent. Revue d'histoire intellectuelle, 31(1): 117-136.

Belorgey Nicolas, Chateignier Frédéric, Hauchecorne Mathieu, PÉNISSAT Étienne. "Théories en milieu militant. Introduction." Sociétés contemporaines, 81: 5-25.

Bentham Jeremy (1789). An Introduction to the Principles of Morals and Legislation. Londres, T. Payne.

BOCHET François (1993). "Naturiens, végétariens, végétaliens et crudivégétaliens dans le mouvement anarchiste français (1895-1938)." 
Invariance, 4(9). [En ligne] http://archivesautonomies.org/lMG/pdf/ ecologieradicale/invariance-n09.pdf [consulté le 11 décembre 2017].

BonNARDEL Yves (1992). «Droits de l'animal, "version française" ». Les Cahiers antispécistes, 2.

Bonnardel Yves, Fergé Sara, Olivier David (2011). La Végéphobie ou le rejet du végétarisme pour les animaux et la discrimination des personnes végétariennes. Quelques réflexions à propos des causes, des conséquences et des perspectives de lutte. s.I., s.n. [En ligne] http://www. veggiepride.org/wp-content/uploads/2016/03/Vegephobie FR lecture. pdf [consulté le 11 décembre 2017].

BOURDIEU Pierre (1984). « La délégation et le fétichisme politique ». Actes de la recherche en sciences sociales, 52-53 : 49-55.

BOURDIEU Pierre (1986). «L'illusion biographique ». Actes de la recherche en sciences sociales, $62: 69-72$.

BOURDIEU Pierre (2002). "Les conditions sociales de la circulation internationale des idées ». Actes de la recherche en sciences sociales, $145: 3-8$.

BouRdieu Pierre (2013). Manet, une révolution symbolique : cours au Collège de France, 1998-2000. Paris, Raisons d'agir/Seuil.

BuRKHARDT Richard (2005). Patterns of Behavior : Konrad Lorenz, Niko Tinbergen and the Founding of Ethology. Chicago, University of Chicago Press.

CARRIÉ Fabien (2015a). « Le savant, le cobaye et l'antivivisectionniste. Circulation, réception et universalisation des innovations expérimentales
Invariance, 4(9). [On line] http://archivesautonomies.org/lMG/pdf/ ecologieradicale/invariance-n09.pdf [accessed on 11 december 2017].

BONNARDEL Yves (1992). "Droits de l'animal, 'version française ?" Les Cahiers antispécistes, 2.

Bonnardel Yves, Fergé Sara, Olivier David (2011). La Végéphobie ou le rejet du végétarisme pour les animaux et la discrimination des personnes végétariennes. Quelques réflexions à propos des causes, des conséquences et des perspectives de lutte. s.I., s.n. [On line] http://www. veggiepride.org/wp-content/uploads/2016/03/Vegephobie FR lecture. pdf [accessed on 11 december 2017].

BOURDIEU Pierre (1985). "Delegation and Political Fetishism." Translated in English by Kathe Robinson. Thesis Eleven, 10-11: 56-70.

BOURDIEU Pierre (1987). "The Biographical Illusion." Translate in to English by Yves Winkin and Wendy Leeds-Hurwitz. Working Papers and Proceeding of the Center for Psychosocial Studies, 14: 1-7.

BOURDIEU Pierre (1999). "The Social Conditions of the International Circulation of Ideas." In Shusterman Richard. Bourdieu: a Critical Reader. Oxford, Blackwell Publishers: 220-228.

Bourdieu PIERRE (2017). Manet: A Symbolic Revolution. Translated in English by Peter Collier and Margaret Rigaud-Drayton. Cambridge, Polity Press.

BuRKHARDT Richard (2005). Patterns of Behavior: Konrad Lorenz, Niko Tinbergen and the Founding of Ethology. Chicago, University of Chicago Press.

CARRIÉ Fabien (2015a). "Le savant, le cobaye et l'antivivisectionniste. Circulation, réception et universalisation des innovations expérimentales 
dans les sciences du vivant (France et Grande-Bretagne, 1860-1890) ». Politix, $111: 69-92$.

CARRIÉ Fabien (2015b). Parler et agir au nom des bêtes. Production, diffusion et réception de la nébuleuse idéologique « animaliste 》 (France et Grande-Bretagne, 1760-2010) (thèse de doctorat en science politique). Nanterre, Université Paris Nanterre.

CARRIÉ Fabien (2017). « La radicalisation de la cause animale en GrandeBretagne dans les années 1960 et 1970 : bricolage et autonomisation d'un porte-parolat hétérodoxe ». Regards sociologiques, 50.

Chavot Philippe (1994). Histoire de l'éthologie. Recherches sur le développement des sciences du comportement en Allemagne, GrandeBretagne et France de 1930 à nos jours (thèse de doctorat en histoire des sciences). Strasbourg, Université Louis Pasteur - Strasbourg 1.

CHARTIER Roger (2013). «Le sens de la représentation ». La Vie des idées. [En ligne] http://www.laviedesides.fr/Le-sens-de-la-representation. html [consulté le 31 octobre 2017].

CHERRY Elisabeth (2010). «Shifting Symbolic Boundaries : Cultural Strategies of the Animal Rights Movement ». Sociological Forum, 25(3) : 450-475.

CORABI Antonella (2009). «Diffuser le mode de vie végan : une critique ». In Réflexions sur la Veggie Pride. [En ligne] http://www.veggiepride.org/ wp-content/uploads/2016/03/Reflexions sur la Veggie Pride-2013brochure-lecture.pdf [consulté le 11 décembre 2017] : 19-26.

Cole Matthew \& MoRgan Karen (2011). « Vegaphobia : Derogatory Discourses of Veganism and the Reproduction of Speciecism in UK National Newspapers ». The British Journal of Sociology, 62(1) : 134-153. Colson Daniel (2001). Petit lexique philosophique de l'anarchisme : de Proudhon à Deleuze?. Paris, Livre de poche. dans les sciences du vivant (France et Grande-Bretagne, 1860-1890)." Politix, 111: 69-92.

CARRIÉ Fabien (2015b). Parler et agir au nom des bêtes. Production, diffusion et réception de la nébuleuse idéologique "animaliste" (France et Grande-Bretagne, 1760-2010) (PhD dissertation, Political science) Nanterre, Université Paris Nanterre.

CARRIÉ Fabien (2017). "La radicalisation de la cause animale en GrandeBretagne dans les années 1960 et 1970: bricolage et autonomisation d'un porte-parolat hétérodoxe." Regards sociologiques, 50.

Chavot Philippe (1994). Histoire de l'éthologie. Recherches sur le développement des sciences du comportement en Allemagne, GrandeBretagne et France de 1930 à nos jours (PhD dissertation, History of science). Strasbourg, Université Louis Pasteur - Strasbourg 1.

ChARTIER Roger (2013). "Le sens de la représentation." La Vie des idées. [On line] http://www.laviedesidees.fr/Le-sens-de-la-representation.htm [accessed on 31 october 2017].

CHERRY Elisabeth (2010). "Shifting Symbolic Boundaries: Cultural Strategies of the Animal Rights Movement." Sociological Forum, 25(3) 450-475.

CORABI Antonella (2009). "Diffuser le mode de vie végan: une critique." In Réflexions sur la Veggie Pride. [On line] http://www.veggiepride.org wp-content/uploads/2016/03/Reflexions sur la Veggie Pride-2013brochure-lecture.pdf [accessed on 11 december 2017]: 19-26.

Cole Matthew \& Morgan Karen (2011). "Vegaphobia: Derogatory Discourses of Veganism and the Reproduction of Speciecism in UK National Newspapers." The British Journal of Sociology, 62(1): 134-153. Colson Daniel (2001). Petit lexique philosophique de l'anarchisme: de Proudhon à Deleuze?. Paris, Livre de poche. 
DerRidA Jacques (2006). L'Animal que donc je suis. Paris, Galilée.

DUBREUIL Catherine-Marie (2013). Libération animale et végétarisation du monde. Ethnologie de l'antispécisme français. Paris, Éditions du Comité des travaux historiques et scientifiques CTHS.

Duranton De Magny Jean (1980). « La mort de Mademoiselle Capart ». L'Antivivisection, 73 : 5-6.

EBEL Marianne \& FIALA Pierre (1983). Langages xénophobes et consensus national en Suisse : 1960-1980. Neuchâtel, Fiala \& Eble.

ELIAS Norbert \& SCOTSON John (1997) [1965]. Logiques de l'exclusion : enquête sociologique au cœur des problèmes d'une communauté. Traduit de l'anglais par Pierre-Emmanuel Dauzat. Paris, Fayard.

FABIANI Jean-Louis (1985). «Science des écosystèmes et protection de la nature ». In CADORET Anne (dir.). Protection de la nature. Histoire et idéologie. Paris, L'Harmattan : 75-83.

FERRY Luc (1992). Le Nouvel Ordre écologique. L'arbre, l'animal et l'homme. Paris, Grasset.

FONTENAY Élisabeth (de) (2008). Sans offenser le genre humain : réflexions sur la cause animale. Paris, Albin Michel.

FONTENAY Élisabeth (de) (2013). «Les animaux considérés ». In CYRULNIK Boris, Fontenay Élisabeth (de), SInger Peter. Les Animaux aussi ont des droits. Paris, Seuil : 124-242.

FRANCIONE Gary (1996). Rain without Thunder : the Ideology of the Animal Rights Movement. Philadelphie, Temple University Press.
DerRIDA Jacques (2008) [2006] The Animal That Therefore IAm. Translated in English by David Wills. New York, Fordham University Press.

DuBREUIL Catherine-Marie (2013). Libération animale et végétarisation du monde. Ethnologie de l'antispécisme français. Paris, Éditions du Comité des travaux historiques et scientifiques CTHS.

Duranton De Magny Jean (1980). "La mort de Mademoiselle Capart." L'Antivivisection, 73: 5-6.

EBEL Marianne \& FIALA Pierre (1983). Langages xénophobes et consensus national en Suisse: 1960-1980. Neuchâtel, Fiala \& Eble.

ELIAS Norbert \& Scotson John (1965). The Establish and the Outsiders. London, Sage.

FABIANI Jean-Louis (1985). "Science des écosystèmes et protection de la nature." In CADORET Anne (ed.). Protection de la nature. Histoire et idéologie. Paris, L'Harmattan: 75-83.

FERRY Luc (1995). The New Ecological Order. Translated in English by Carol Volk. Chicago, University of Chicago Press.

FONTENAY Élisabeth (DE) (2008). Sans offenser le genre humain: réflexions sur la cause animale. Paris, Albin Michel.

FONTENAY Élisabeth (DE) (2013). "Les animaux considérés." In CYRULNIK Boris, Fontenay Élisabeth (de), Singer Peter. Les Animaux aussi ont des droits. Paris, Seuil: 124-242.

FrancIONE Gary (1996). Rain without Thunder: the Ideology of the Animal Rights Movement. Philadelphie, Temple University Press. 
FRANCIONE Gary (1998). «Animal Rights and New Welfarism ». In BEKOFF Marc (dir.). Encyclopedia of Animal Rights and Animal Welfare. Londres/ Chicago, Fitzroy Dearborn : 45.

GOFFMAN Erving (1989). Stigmate : les usages sociaux des handicaps. Traduit de l'anglais par Alain Kinm. Paris, Minuit.

Granjon Marie-Christine (1985). L’Amérique de la contestation : les années 60 aux États-Unis. Paris, Presses de la Fondation nationale des sciences politiques.

GUSFIELD Joseph (1994). «The Reflexivity of Social Movements : Collective Behavior and Mass Society Theory Revisity ». In LARANA Enrique, JoHnStON Hank, GuSFIELD Joseph (dir.). New Social Movements : From Ideology to Identity. Philadelphie, Temple University Press.

HABERMAS Jürgen (1990). La Technique et la science comme idéologie. Traduit de l'allemand et préfacé par Jean-René Ladmiral. Paris, Gallimard.

Hardouin-Fugier Élisabeth, Reus Estiva, Olivier David (2002). Luc Ferry ou le rétablissement de l'ordre. L'humanisme est-il anti-égalitaire ?. Lyon, Tahin Party.

HARE Richard Mervyn (1962). Freedom and Reason. Oxford, Oxford University Press.

HauchecoRne Mathieu (2012). «Faire du terrain en pensée politique ». Politix, 100 : 149-165.

Hauchecorne Mathieu \& Pudal Romain (2016). « La philosophie américaine en France ». In CHARLE Christophe \& JEANPIERRE Laurent
Francione Gary (1998). "Animal Rights and New Welfarism." In BekofF Marc (ed.). Encyclopedia of Animal Rights and Animal Welfare. Londres/ Chicago, Fitzroy Dearborn: 45.

Goffman Erving (1965). Stigma. Notes on the Management of Spoiled Identity. New York, Simon \& Schuster.

Granjon Marie-Christine (1985). L'Amérique de la contestation: les années 60 aux États-Unis. Paris, Presses de la Fondation nationale des sciences politiques.

GuSFIELD Joseph (1994). "The Reflexivity of Social Movements: Collective Behavior and Mass Society Theory Revisity." In LARANA Enrique, JOHNSTON Hank, GusfielD Joseph (eds.). New Social Movements: From Ideology to Identity. Philadelphie, Temple University Press.

Habermas Jürgen (1992). "Technology and Science as 'Ideology." In INGRAM David \& SIMON Julia. Critical Theory: The Essential Readings. New York, Paragon House: 117-145

HARdouin-Fugier Élisabeth, Reus Estiva, Olivier David (2002). Luc Ferry ou le rétablissement de l'ordre. L'humanisme est-il anti-égalitaire ?. Lyon, Tahin Party.

HARE Richard Mervyn (1962). Freedom and Reason. Oxford, Oxford University Press.

HAuChECORNE Mathieu (2012). "Faire du terrain en pensée politique." Politix, 100: 149-165.

HAUCHECORNE Mathieu \& PUdAL Romain (2016). "La philosophie américaine en France." In Charle Christophe \& JeAnPIERRE Laurent (eds.). La Vie intellectuelle en France. II. De 1914 à nos jours. Paris, Seuil: 827-832. 
(dir.). La Vie intellectuelle en France. II. De 1914 à nos jours. Paris, Seuil : 827-832.

HoffmanN Hasso (2003). Repräsentation. Studien zur Wort- und Begriffgeschichte von der Antike bis ins 19. Jarhundert. Berlin, Duncker \& Humblot.

KARCher Karin, OlivieR David, VIDAL Léo (1992). « Interview de Tom Regan ". Les Cahiers antispécistes lyonnais, 2. [En ligne] http:// www.cahiers-antispecistes.org/interview-de-tom-regan/ [consulté le 31 octobre 2017]

KHEEL Marti (2004). « Vegetarianism and Ecofeminism : Toppling Patriarchy with a Fork ». In SAPONTZIS Steve (dir.). Food for Thought: the Debate over Eating Meat. New York, Prometheus Books : 327-341.

KrIEg-Planque Alice (2009). La Notion de formule en analyse du discours cadre théorique et méthodologique. Besançon, Presses Universitaires de Franche-Comté.

LAGROYE Jacques (2003). "Les processus de politisation ». In LAGROYE Jacques (dir.). La Politisation. Paris, Belin.

LA MANIPULATION VERBALE (1998). " Agression à antifascistland - ".. antispécistes dans une foule d'humanistes" ". Les Cahiers antispécistes. Réflexion et action pour l'égalité animale. 15-16. [En ligne] http://www. cahiers-antispecistes.org/agression-a-antifascistland-antispecistesdans-une-foule-dhumanistes/ [consulté le 12 décembre 2017].

LAMONT Michèle (1987). « How to Become a Dominant French Philosopher : The Case of Jacques Derrida ». American Journal of Sociology, 93(3) 584-622.

MAcAdam Doug (1989). «The Biographical Consequences of Activism ». American Sociological Review, 54(5) : 744-760.
HoffmANN Hasso (2003). Repräsentation. Studien zur Wort- und Begriffgeschichte von der Antike bis ins 19. Jarhundert. Berlin, Duncker \& Humblot.

Karcher Karin, Olivier David, Vidal Léo (1992). "Interview de Tom Regan." Les Cahiers antispécistes lyonnais, 2. [On line] http://www. cahiers-antispecistes.org/interview-de-tom-regan/ [accessed on 31 octobre 2017].

KHEEL Marti (2004). "Vegetarianism and Ecofeminism: Toppling Patriarchy with a Fork." In SAPONTZIS Steve (ed.). Food for Thought: the Debate over Eating Meat. New York, Prometheus Books: 327-341.

KRIEG-PlANQUE Alice (2009). La Notion de formule en analyse du discours: cadre théorique et méthodologique. Besançon, Presses Universitaires de Franche-Comté.

LAGROYE Jacques (2003). "Les processus de politisation." In LAGROYE Jacques (ed.). La Politisation. Paris, Belin.

La manipulation verbale (1998). "Agression à antifascistland - '.. antispécistes dans une foule d'humanistes."' Les Cahiers antispécistes. Réflexion et action pour l'égalité animale. 15-16. [On line] http://www. cahiers-antispecistes.org/agression-a-antifascistland-antispecistesdans-une-foule-dhumanistes/ [accessed on 12 december 2017].

LAMONT Michèle (1987). "How to Become a Dominant French Philosopher: The Case of Jacques Derrida." American Journal of Sociology, 93(3) 584-622.

MacAdam Doug (1989). "The Biographical Consequences of Activism." American Sociological Review, 54(5): 744-760.

MunRo Lyle (2002). "The Animal Activism of Henry Spira." Society and Animals, 10(2): 173-191. 
MunRo Lyle (2002). "The Animal Activism of Henry Spira ». Society and Animals, 10(2) : 173-191.

OLIVIER David (1993). «Problème entre l'AIDAet les cahiers antispécistes». Les Cahiers antispécistes Iyonnais, 8. [En ligne] http://www.cahiersantispecistes.org/problemes-entre-laidaet-les-cahiers-antispecistes/ [consulté le 31 octobre 2017]

Olivier David (2000). "Promenades sur Internet ». Les Cahiers antispécistes. Réflexion et action pour l'égalité animale, 18. [En ligne] http://www.cahiers-antispecistes.org/promenades-sur-internet/ [consulté le 31 octobre 2017]

Olivier David (2002). "Réflexions sur la Veggie Pride ». Les Cahiers antispécistes. Réflexion et action pour l'égalité animale, 21. [En ligne] http://www.cahiers-antispecistes.org/reflexions-sur-la-veggie-pride/ [consulté le 31 octobre 2017]

OuedRaogo Arouna (1994). Le Végétarisme, esquisse d'histoire sociale. Ivry-sur-Seine, INRA.

RORTY Richard (2008). « Entre Kant et Dewey : la situation actuelle de la philosophie moderne ». Revue internationale de philosophie, 245 : 235-256.

ROUEFF Olivier (2013). « Les homologies structurales : une magie sociale sans magiciens ? La place des intermédiaires dans la fabrique des valeurs ». In COULANGEON Philippe \& Duval Julien (dir.). Trente ans après la distinction, de Pierre Bourdieu. Paris, La Découverte : 153-164.

SAWICKI Frédéric (2001). "Les partis politiques comme entreprises culturelles ». In CÉFAİ Daniel (dir.). Cultures politiques. Paris, Presses Universitaires de France (PUF).

SINGER Peter (1973). «Animal Liberation ». New York Review of Books, 5 avril 1973.
OLIVIER David (1993). "Problème entre l'AIDA et les cahiers antispécistes." Les Cahiers antispécistes lyonnais, 8. [On line] http://www.cahiersantispecistes.org/problemes-entre-laidaet-les-cahiers-antispecistes/ [accessed on 31 october 2017].

Olivier David (2000). "Promenades sur Internet." Les Cahiers antispécistes. Réflexion et action pour l'égalité animale, 18. [On line] http://www.cahiers-antispecistes.org/promenades-sur-internet/ [accessed on 31 octobre 2017].

Olivier David (2002). "Réflexions sur la Veggie Pride." Les Cahiers antispécistes. Réflexion et action pour l'égalité animale, 21. [On line] http:// www.cahiers-antispecistes.org/reflexions-sur-la-veggie-pride/ [accessed on 31 octobre 2017]

OuedRAogo Arouna (1994). Le Végétarisme, esquisse d'histoire sociale. Ivry-sur-Seine, INRA.

RoRTY Richard (2008). "Entre Kant et Dewey: la situation actuelle de la philosophie moderne." Revue internationale de philosophie, 245: 235-256.

RouefF Olivier (2013). "Les homologies structurales: une magie sociale sans magiciens? La place des intermédiaires dans la fabrique des valeurs." In COULANGEON Philippe \& DUVAL Julien (eds.). Trente ans après la distinction, de Pierre Bourdieu. Paris, La Découverte: 153-164.

SAWICKI Frédéric (2001). "Les partis politiques comme entreprises culturelles." In CÉFAï Daniel (ed.). Cultures politiques. Paris, Presses Universitaires de France (PUF).

Singer Peter (1973). "Animal Liberation." New York Review of Books, 5 april 1973.

SINGER Peter (1975). Animal Liberation. A New Ethics for our Treatment of Animals. New York, New York Review/Random House. 
Singer Peter (1986). Applied Ethics. New York, Oxford University Press.

SINGER Peter (1991). Le Mouvement de libération animale : sa philosophie, ses réalisations, son avenir. Traduit de l'anglais par David Olivier. Lyon, F. Blanchon.

SINGER Peter (1993) [1975]. La Libération animale. Traduit de l'anglais par Louise Rousselle, traduction relue par David Olivier. Paris, Grasset.

SINGER Peter (1996). Rethinking Life and Death : the Collapse of our Traditional Ethics. New York, St. Martin's Griffin.

Singer Peter (1998). Ethics Into Action : Henry Spira and the Animal Rights Movement. Lanham, Rowan \& Littlefield.

SINGER Peter (2000). L'Égalité animale expliquée aux humain-es. Lyon, Tahin Party.

SINGER Peter (2002). « R. M. Hare's Achievements in Moral Philosophy. A Talk for the Memorial Service at St Mary's Church, Oxford, 25 May, 2002 ». Utilitas, 14(3) : 309-317.

SINGER Peter (2006). «Éthique appliquée ». In DORTIER Jean-François (dir.). Le Dictionnaire des sciences humaines. Paris, Presses Universitaires de France (PUF) : 398-401.

SINTOMER Yves (2013). « Le sens de la représentation politique : usages et mésusages d'une notion ». Raisons politiques, 50(2) : 13-34.

SKoRNICKI Arnault \& TOURNADRE Jérôme (2015). La Nouvelle Histoire des idées politiques. Paris, La Découverte.

STocZKowskı Wiktor (1999). « La pensée de l'exclusion et la pensée de la différence : quelle cause pour quel effet ? ». L'Homme, 150 : 41-57.
SINGER Peter (1985). The Animal Liberation Movement: its Philosophy, its Achievements, and its future. Nottingham, Old Hammond Press.

SINGER Peter (1986). Applied Ethics. New York, Oxford University Press.

Singer Peter (1996). Rethinking Life and Death: the Collapse of our Traditional Ethics. New York, St. Martin's Griffin.

SINGER Peter (1998). Ethics Into Action: Henry Spira and the Animal Rights Movement. Lanham, Rowan \& Littlefield.

SINGER Peter (2000). L'Égalité animale expliquée aux humain-es. Lyon, Tahin Party.

Singer Peter (2002). "R. M. Hare's Achievements in Moral Philosophy. A Talk for the Memorial Service at St Mary's Church, Oxford, 25 May, 2002." Utilitas, 14(3): 309-317.

SINGER Peter (2006). "Éthique appliquée." In DorTIER Jean-François (ed.). Le Dictionnaire des sciences humaines. Paris, Presses Universitaires de France (PUF): 398-401.

SintOMER Yves (2013). "Le sens de la représentation politique: usages et mésusages d'une notion.” Raisons politiques, 50(2): 13-34.

SKornICKI Arnault \& TOURnAdRe Jérôme (2015). La Nouvelle Histoire des idées politiques. Paris, La Découverte.

StoczKowskı Wiktor (1999). "La pensée de l'exclusion et la pensée de la différence: quelle cause pour quel effet ?" L'Homme, 150: 41-57.

TRAînı Christophe (2010). La Cause animale, 1820-1980: essai de sociologie historique. Paris, Presses Universitaires de France (PUF). 
Traînı Christophe (2010). La Cause animale, 1820-1980 : essai de sociologie historique. Paris, Presses Universitaires de France (PUF).

TRAîNı Christophe (2012). "Entre dégoût et indignation morale. Sociogenèse d'une pratique militante $"$. Revue française de science politique, 62(4) : 559-581.

WILSON David (2002). " Animal Psychology and Ethology in Britain and the Emergence of Professional Concern for the Concept of Ethical Cost ». Studies in History and Philosophy of Biological and Biomedical Sciences, $33: 235-261$.

Woods Abigaïl (2012). "From Cruelty to Welfare : the Emergence of Farm Animal Welfare in Britain, 1964-71 ». Endeavour, 36(1) : 14-22.
TRAîNI Christophe (2012). "Entre dégoût et indignation morale. Sociogenèse d'une pratique militante." Revue française de science politique, 62(4): 559-581.

WILson David (2002). "Animal Psychology and Ethology in Britain and the Emergence of Professional Concern for the Concept of Ethical Cost." Studies in History and Philosophy of Biological and Biomedical Sciences, 33: 235-261.

Woods Abigaïl (2012). "From Cruelty to Welfare: the Emergence of Farm Animal Welfare in Britain, 1964-71." Endeavour, 36(1): 14-22. 